THE FOUNDATIONS OF

INTERNATIONAL HUMAN RIGHTS

LAW: A SOCIOLOGICAL INQUIRY*

Chris Thornhill ${ }^{1}$

AS BASES DO DIREITO INTERNACIONAL DOS DIREITOS

HUMANOS: UMA INVESTIGAÇÃO SOCIOLÓGICA

\begin{abstract}
This article is intended to provide a foundation for broader sociological analysis of the rise of international human rights law. It uses a historicalsociological approach to argue that the increasing importance of international human rights norms is not, as usually claimed, the result of normative agreements between actors and organizations located outside national societies, placing checks on the power of existing sovereign states. On the contrary, the emergence of international human rights regimes can be linked to formative processes embedded in national societies, and it reveals deep continuities with inner-societal patterns of institution building and state construction. Most notably, international human rights law, especially where it penetrates into domestic legal orders, helps to elevate the robustness and the autonomy of domestic political institutions, and it contributes in important ways to the stabilization of national states, within their own societies, as distinctively sovereign organizations.
\end{abstract}

Keywords: International human rights law. Society. Domestic legal orders.
RESUMO: Este artigo destina-se a fornecer uma base para análise sociológica mais ampla da ascensão do direito internacional dos direitos humanos. Utiliza uma abordagem histórico-sociológica para argumentar que a crescente importância das normas internacionais de direitos humanos não é, como se diz, o resultado de acordos normativos entre atores e organizações localizadas fora das sociedades nacionais, colocando o controle dos poderes dos estados soberanos existentes. Pelo contrário, o surgimento de regimes internacionais de direitos humanos pode ser ligado a processos formativos incorporados em sociedades nacionais e revela profundas continuidades com padrões sociais internos presentes nas construções de instituições e na construção do Estado. Em particular, o direito internacional dos direitos humanos, especialmente quando penetra nas ordens jurídicas internas, contribui para elevar a robustez e a autonomia das instituições políticas domésticas e contribui de forma importante para a estabilização dos Estados nacionais, dentro de suas próprias sociedades, como distintamente Organizações soberanas.

Palavras-chave: Direito internacional dos direitos humanos. Sociedade. Ordens legais nacionais.

\footnotetext{
* Early versions of this article were presented at conferences at the Humboldt University in Berlin (2013), the University of Modena (2013), the Universidade Federal do Rio de Janeiro (2013), and Pázmány Péter Catholic University, Budapest (2013). A subsequent version was presented at the Tribunal Regional Federal da 4a Região (TRF4) in Porto Alegre, Brazil (2014). My gratitude is due to all participants in debates at these events. I should also like to thank Atina Krajewska for discussions during the writing of this article. Most of the research for this article was funded by the European Research Council (Advanced Grant 323656 - STC). Some ideas first expounded in this article have now appeared in different form in my book: A Sociology of Transnational Constitutions: Social Foundations of the Post-National Legal Structure (Cambridge: Cambridge University Press, 2016). This book is available in Open Access at the following link: https://www.research.manchester.ac.uk/portal/files/40835174/SOCIOLOGY_OF_ TRANSNATIONAL_CONSTITUTIONS.pdf.

${ }^{1}$ Professor titular de direito da University of Manchester. Autor do livro: A Sociology of Transnational Constitutions: the social foundations of the post-national legal structure. Cambridge: Cambridge University Press (Cambridge Studies in Law and Society), 2016.
} 


\section{INTERNATIONAL HUMAN RIGHTS LAW AND THE CRISES OF THE NATION STATE}

In most parts of the world, the classical design of the national state has recently been supplanted by a system of political organization, in which the authority and competences of national institutions are restricted by international legal norms, usually applied by judicial bodies. Indeed, the general development of national statehood since 1945 is marked, albeit in regionally variable fashion, by one primary trajectory, which increasingly makes it inaccurate to talk of statehood as a specifically national phenomenon. On one hand, externally, statehood is shaped by the increasing impact of international organizations, especially those with judicial competence (for example, the United Nations (UN), the World Trade Organization (WTO), the International Labour Organization (ILO)), on procedures for legislation in national polities. As a result of this, national legislation is now almost always, to some degree, co-determined by internationally justiciable norms. On the other hand, internally, statehood is shaped by the directly linked rise of national courts, which, typically acting in close comity with supra- or international judiciaries, conduct judicial review of national law making, and impose normative constraints on acts of democratically mandated legislators. ${ }^{2}$ As a result of this, similarly, national laws are pre-defined - however variably - by transnational legal principles.

In both respects, contemporary statehood is widely marked by a constitutional template, through which judicially imposed norms, usually of international provenance, have assumed dramatically increased importance in national legislation. The consequence of this is that transnational judicial democracy has now become a prevalent, even the dominant, model of national statehood. This model first became prominent in the postauthoritarian polities that were established, experimentally, after 1945. It became more

\footnotetext{
${ }^{2}$ Note, therefore, the use of the term 'judicial review revolution' to describe recent changes in democratic design in Thierry S. Renoux, 'Le Conseil constitutionnel et le pouvoir judiciaire en France dans le modèle européen de contrôle de constitutionnalité des lois.' Revue internationale de droit comparé 46(3) (1994): 891-899; 892. Ii is often observed that pure parliamentary sovereignty has 'faded away' across the globe. See Tom Ginsburg, 'Introduction: The Decline and Fall of Parliamentary Sovereignty' in Tom Ginsburg (ed), Judicial Review in New Democracies: Constitutional Courts in Asian Cases (Cambridge: Cambridge University Press, 2003), pp. 1-20; 3.
} 
widespread through the democratic transitions from the 1970s to the 1990s. Now, with variations, this model is increasingly universal, and it is able even to shape the form of polities in which the immediate reception of international law has traditionally been obstructed. For instance, it penetrates polities (e.g. the UK), which are constitutionally resistant to higher-order legal norms; ${ }^{3}$ it penetrates polities (e.g. China), ${ }^{4}$ which have not yet evolved fully enforceable democratic constitutions, and which historically rejected international law as Western imperialist artifice; it penetrates polities, for example in Southern Africa, whose basic domestic legal order remains uncertain, pluralistic, often informal; ${ }^{5}$ it even penetrates polities, for instance in North Africa, where historical and cultural reconditions pull against easy acceptance of universal international norms. ${ }^{6}$

At the centre of this emerging pattern of statehood is the growing force of international human rights law, including the law created and enforced in special human rights system, such as bodies applying the European Convention on Human Rights (ECHR) and the American Convention on Human Rights (ACHR). ${ }^{7}$ Human rights law is now normally taken as the primary basis for review of legislation, and, in different ways in different settings, it forms the criterion of legitimacy for new laws - both in and beyond national jurisdictions. In international society, human rights law places restrictions on the free exercise of decision-making autonomy by national states, and it is used by inter- or supranational courts to dictate the parameters of legitimate national legislation and executive actions. Within many national polities, individual persons can obstruct legislation

\footnotetext{
${ }^{3}$ Since the Factortame cases, the UK national parliament is clearly, in part, subordinate to European law. See Anthony Bradley, 'The Sovereignty of Parliament - Form or Substance?' in Jeffrey Jowell and Dawn Oliver (eds), The Changing Constitution, $7^{\text {th }}$ edition (Oxford: Oxford University Press, 2011), pp. 35-69; 56. Note also that the 1998 Human Rights Act means that international human rights law has been integrated as part of a 'constitutional statute'. See Roger Masterman, 'Taking the Strasbourg Jurisprudence into Account: Developing a 'Municipal Law of Human Rights' under the Human Rights Act.' International and Comparative Law Quarterly 54(4) (2005): 907-931; 913.

${ }^{4}$ Guobin Zhu, 'Constitutional Review in China: An Unaccomplished Project or a Mirage?' Suffolk University Law Review 63 (2010): 101-129; 109.

${ }^{5}$ Kwasi Prempeh, 'Marbury in Africa: Judicial Review and the Challenge of Constitutionalism in Contemporary Africa.' Tulane Law Review 80 (2006): 1239-1323; 1241, 1242. Generally, see Kwasi Prempeh, 'Africa's "constitutionalism revival”: False Start or New Dawn.' International Constitutionalism 5 (2007): 469-506; 505.

${ }^{6}$ Mona El-Ghobashy, 'Constitutionalist Contention in Contemporary Egypt.' American Behavioral Scientist 51 (2008): 1590-1610; 1613.

${ }^{7}$ Notably, to support this inclusion, the Inter-American Court of Human Rights (ACtHR) perceives itself as appointed to interpret and even to construct an international corpus juris. See Inter-American Court of Human Rights, Comunidad indígena Yakye Axa v Paraguay (2005).
} 
by appealing to international courts, single acts of legislation are routinely subject to judicial review for conformity with international human rights norms, and most constitutions expressly authorize national courts to enforce international norms regarding rights. ${ }^{8}$ Even where this is not seen as a formal imperative, national judges show extensive regard for the rights jurisprudence of foreign courts and inter- or supranational judicial bodies, and international human rights norms influence legislation and judicial opinions in often rather informal fashion. ${ }^{9}$ Overall, rights form a vocabulary of legitimacy that locks together the national and international dimensions of an emerging global political system, and laws are increasingly authorized above, through and across the divisions between national polities (i.e. transnationally) by the extent to which, at different levels, they derive legitimacy from judicial bodies, which screen the content of laws through reference to international rights norms.

It is commonly asserted that this new model of statehood is conditioned by forces located outside national societies, and the increasingly dense interaction between national statehood and international human rights law is widely seen as a phenomenon that is externally imposed upon states. The rise of international human rights norms is commonly described as a symptom of legal globalization, and it is observed as a process which originates outside national societies, in relative indifference to the authority of national states, and which compels national institutions to act within externally ordained normative limits, so diminishing the effective power of sovereign states. ${ }^{10}$ Legal globalization, in fact,

\footnotetext{
${ }^{8}$ See pp. XXX below.

${ }^{9}$ See for example Mirna E. Adjami, 'African Courts, International Law, and Comparative Case Law: Chimera or Emerging Human Rights Jurisprudence?’ Michigan Journal of International Law 24 (2002): 103-167; 124-5, 130.

${ }^{10}$ This view is commonplace across the political spectrum. But see especially Jan Klabbers, Anne Peters and Geir Ulfstein, The Constitutionalization of International Law (Oxford: Oxford University Press, 2009), pp. 154, 179; Johan D. van der Vyver, 'Sovereignty and Human Rights in Constitutional and International Law.' Emory International Law Review 5 (1991): 321-343; 426-7. For a cross-section of prominent assertions of this claim see Philip C. Jessup, 'The Subjects of a Modern Law of Nations.' Michigan Law Review 45(4) (1947): 383-408; 406; Richard Falk, The Status of Law in International Society (Princeton: Princeton University Press, 1970), xiii; Jost Delbrueck, 'International Protection of Human Rights and State Sovereignty.' Indiana Law Journal 57 (1982): 567-578; 572; Louis Henkin, 'Human Rights and State "Sovereignty".' Georgia Journal of International and Comparative Law 25 (1995-96): 31-44; 38; Harold Hongju Koh, 'How is International Human Rights Law enforced?' Indiana Law Journal 74(4) (1998): 1397-1477; 1410; Allan Rosas, 'State Sovereignty and Human Rights: Towards a Global Constitutional Project.' Political Studies 43 (1995): 61-78; 75; Karolina Milewicz, 'Emerging Patterns of Global Constitutionalization: Toward a Conceptual Framework.' Indiana Journal of Global Legal Studies 16(2) (2008): 413-436; 422, 432; Jeremy A. Rabkin, Law without Nations? Why Constitutional Government requires Sovereign States (Princeton: Princeton University Press, 2007), p. 70; Ernest A.
} 
is almost always associated with a relativization of state authority, in which the rise of a global legal arena places both formal and informal restrictions on powers classically exercised by sovereign states. One very eminent commentator of these processes observed simply that international human rights law has led to a 'significant erosion of state sovereignty'. ${ }^{11}$ This view of international law is not universal, and, in contemporary debate, there are noteworthy exceptions to it. ${ }^{12}$ However, most analysis of international law reflects a residually positivistic view of the sovereign power of national states, and it sees such power as objectively constrained by international human rights law. ${ }^{13}$ This outlook reflects certain deeply entrenched perceptions of international law, and of human rights law in particular. On one hand, this outlook reflects the view that the growth of international law after 1945 was promoted as a break with classical, national processes of sovereign state building and autonomous legal formation: that is, it suggests that the attribution of rights to persons under international law was intended consciously to curtail the sovereign powers of national states, which had become dangerously expansive in the authoritarian polities of interwar Europe. ${ }^{14}$ On the other hand, this outlook is still defined

Young, 'The Trouble with Global Constitutionalism.' Texas International Law Journal 38 (2003), pp. 527-546; 536, 542. See also Dieter Grimm, Die Zukunft der Verfassung (Frankfurt am Main: Suhrkamp, 1991), p. 31; Martin Loughlin, 'In defence of Staatslehre.' Der Staat 48(1) (2009): 1-27.

${ }^{11}$ Louis Henkin, 'That "S" Word: Sovereignty, and Globalization, and Human Rights, Et Cetera." Fordham Law Review 68(1) (1999): 1-14; 4.

${ }^{12}$ For alternatives see Andrew Moravcsik, 'Why the European Union Strengthens the State: Domestic Politics and International Cooperation', Center for European Studies, Harvard University, Working Paper Series \#52 pp. 2, 3, 36; Thomas Risse and Kathryn Sikkink, 'The Socialization of International Human Rights Norms into Domestic Practices: Introduction', in Thomas Risse-Kappen, Stephen C. Ropp and Kathryn Sikkink (eds), The Power of Human Rights: International Norms and Domestic Change (Cambridge: Cambridge University Press, 1999), pp. 1-38; Tom Ginsburg, 'Locking in Democracy: Constitutions, Commitment and International Law.' University of Illinois College of Law, Law and Economics Working Papers \# 55 (2006), pp. 23; Kalypso Nicolaidis and Gregory Shaffer, 'Transnational Mutual Recognition Regimes: Governance without Global Government.' Law and Contemporary Problems 68 (2005): 263-317; 314; Emilie M. Hafner-Burton, Kiyoteru Tsutsui and John W. Meyer, 'International Human Rights and the Politics of Legitimation: Repressive States and Human Rights Treaties.' International Sociology 23 (2008): 115-141; 135. See in particular the important analysis in Anne-Marie Slaughter and William Burke-White, 'The Future of International Law is Domestic (or, the European Way of Law).' Harvard International Law Journal 47(2) (2006): 327-352; For a recent, specifically sociological account of motives for states to accept constraint through international human rights norms see Christine Min Wotipka and Kiyoteru Tsutsui, 'Global Human Rights and State Sovereignty: State Ratification of International Human Rights Treaties 1965-2001.' Sociological Forum 23(4) (2008): 724-754; $725,737$.

${ }^{13}$ See Mónica García-Salmones Rovira, The Project of Positivism in International Law (Oxford: Oxford University Press, 2013), p. 357

${ }^{14}$ This was expressed in Art 6 of the Charter of the Nuremberg Tribunal. For analysis see Elies van Sliedregt, Individual Criminal Responsibility in International Law (Oxford University Press, 2012), p. 61. In Europe, there is exhaustive documentation of the turn against nation-statism in the formation of the Council of Europe and the framing of the 
by the dualism/monism dichotomy that marked early approaches to international law, both sides of which, however distinctly, conceived the power of states as externally restricted by norms of international law. ${ }^{15}$ More generally, then, this outlook is based in the broadly positivist assumption that states exist as simple aggregates of institutions, which, in their domestic actions, exercise a simple monopoly of power across society, ${ }^{16}$ and which, in their international actions, are constructed as simple legal persons, capable of performing basic international functions. ${ }^{17}$ On this classical perspective, international law flows immediately from the acts of sovereign states, and international law necessarily presupposes the prior existence of fully elaborated states, acting as static, integrally sovereign entities. ${ }^{18}$ In this characterization, however, although states originally authorize international law, they forfeit at least part of their sovereign autonomy because of their eventual compliance with it, especially insofar as international law accords basic rights to single persons within existing states. ${ }^{19}$ On the standard account, the rising domestic penetration of international human rights law means that national sovereignty appears as a necessarily vanishing resource, ${ }^{20}$ and the contemporary emphasis on judicial power and single rights in national constitutions is testimony to a progressive loss of state

European Convention on Human Rights. See notably Ed Bates, The Evolution of the European Convention on Human Rights. From its Inception to the Creation of a Permanent Court of Human Rights (Oxford: Oxford University Press, 2010), p. 8. This is widely accepted as signifying a breach between pre-1945 and post-1950 legal presumptions. For recent comment see Williams, Andrew 'Burying, not Praising the European Convention on Human Rights: A Provocation', in Neil Walker, Jo Shaw and Stephen Tierney (eds). Europe's Constitutional Mosaic (Oxford: Hart, 2011), pp. 75-96; 79; Devin O. Pendas, 'Toward World Law? Human Rights and the Failure of the Legalist Paradigm of War', in Stefan-Ludwig Hoffmann (ed), Human Rights in the Twentieth Century (Cambridge: Cambridge University Press, 2011), pp. 215-236; 215.

${ }^{15}$ Classical dualist approaches obviously viewed international law as a limit on state power. This is clear in the works of Carl Schmitt and Heinrich Triepel. But the limiting of state power was also a motivation for earlier monist theorists. See Hans Kelsen, Das Problem der Souveränität und die Theorie des Völkerrechts. Beitrag zu einer reinen Rechtslehre (Tübingen: J.C.B. Mohr, 1920), p. 12.

${ }^{16}$ See Alfred Verdross and Bruno Simma, Universelles Völkerrecht. Theorie und Praxis (Berlin: Duncker und Humblot, 1976), p. 49

17 Ibid p. 49

${ }^{18}$ See the classical arguments in Hans Kelsen, 'The Principle of Sovereign Equality as a Basis for International Organization.' The Yale Law Journal 53(2) (1944): 207-2020; 208; Alfred Verdross, Völkerrecht (Vienna: Springer, 1950), p. 7.

${ }^{19}$ Famously, for example, Georges Scelle claimed simply that the notion of sovereignty was 'incompatible' with the idea of international law - or even with the idea of law itself: Georges Scelle, Précis de droit des gens. Principes et systématique (Paris: Sirey, 1932), p. 13. See also Sir Robert Jennings, 'Sovereignty and International Law' in Gerard Kreijen (ed.), State, Sovereignty and International Governance (Oxford: Oxford University Press, 2002), pp. 27-44; 29.

${ }^{20}$ See Jessup at note 10 above. 
autonomy. ${ }^{21}$ Contemporary debates about sovereignty and international law thus generally uphold essentially positivist principles, claiming, either affirmatively or critically, that the historical period of sovereign statehood and national autonomy is now over, and global society is defined by the fact that international human rights norms increasingly overrule historically solid sovereign state institutions.

The purpose of this article is to challenge such widespread ideas about national statehood, sovereignty, international law, and it argues that common presumptions regarding the relation between legal institutions in the national and the international domains result from deep misconceptions about statehood and national society. This article claims that the national and the international or global levels of legal formation ought to be seen, not as conflicting, but instead as deeply interlinked and mutually constitutive legal spheres, and it aims to show that the institutions situated in these different spheres are causally and formatively interconnected, such that no strict distinction can be made between them. In particular, it attempts to show that the domain of international human rights law, far from emerging as an external check on national institutions, is produced - in part - from functional pressures within domestic societies: the normative structure of international human rights law evolves on the sociological foundation of national law, and in many ways it reinforces vital dimensions of national law. To substantiate these claims, this article outlines a distinctive sociological approach to the growth of international human rights law and its impact on national states, and it employs this approach to contest more standard paradigms in international legal reflection. Existing views of the relation between statehood and international law, it claims, are shaped by a highly pre-constructed, legally internalistic, notion of statehood. ${ }^{22}$ If we adopt a more sociologically refined approach to international law, however, we can see that states do not appear in the form of conclusively ordered legal entities, which, once developed, perform essentially unchanging functions throughout a national society in its totality, and we can recognize that, historically, states did not statically pre-exist international human

\footnotetext{
${ }^{21}$ See also the argument in Ran Hirschl, Towards Juristocracy. The Origins and the Consequences of the New Constitutionalism (Cambridge, Mass: Harvard University Press, 2004).

${ }^{22}$ For similar claims see Robert H. Jackson and Carl G. Rosberg, 'Sovereignty and Underdevelopment: Juridical Statehood in the African Crisis.' The Journal of Modern African Studies 24(1) (1986): 1-31,
} 
rights law as completely formed, formally voluntaristic, legal personalities. Up to a very late stage in modern society, in fact, most national states were only partly evolved, and inner-societal pressures obstructed, and threatened repeatedly (often successfully) to reverse, their development. National states cannot, therefore, be conceived as simple fixed sovereign entities, which are able in equal fashion to form, give authority to, and act as the precondition for, international law (or, indeed, any law). On the contrary, states are in a constant process of formation, and their powers of sovereign social control are at the centre of deeply unsettling political-systemic conflicts. In particular, insofar as they exercise control of national societies, national states are constantly exposed to, and unsettled by, pervasive pressures of inclusion. That is to say, modern states first evolved as societal institutions that were expected to create conditions for the general inclusion of entire national societies. To achieve this, they were required progressively to extend their reach into society, and to resolve deep-lying conflicts between different groups at different locations in society. Most states, however, have struggled to meet the inclusionary demands directed towards them, their ability to stabilize an inclusionary normative order has remained precarious, and they have repeatedly been brought to crisis by the expectations of inclusion, with which, from their initial emergence, they were confronted. If we examine statehood through this sociological perspective, then, we can observe that the evolution of national states is not separate from the rise of international human rights law: international human rights law did not develop as a corpus of externally constructed norms, and the effective formation of states has been integrally affected by, among other factors, the extent to which they assimilate international human rights law. The interaction between national states and the system of international law, especially international directives focused on human rights, is clearly a vital and very distinctive feature of contemporary statehood, and it is not reasonable to imagine that this does not have pervasive repercussions for the institutions that national states comprise. Indeed, the structure of national states, insecurely elaborated at best, is necessarily subject to farreaching transformation by the fact that states recognize international laws, and that they allow international legal norms law to penetrate deeply into processes of national law making and institution building. 
On this basis, this article attempts to make a distinctive contribution to debate about international human rights law. First, it examines the formative impact of international rights norms on state construction across a range of national societies. In so doing, it proposes a sociological method to reconstruct the rise of international human rights law, and it aims to explain the recent international consolidation of human rights by illuminating the inner-societal pressures to which human rights typically respond. In this respect, it seeks to lay the methodological foundations for a new field of research in international law: to date, we lack a sociological construction of international human rights. ${ }^{23}$ This article offers a new paradigm for elucidating the standing and function of human rights in international society and for assessing the causal foundations of rights norms. From the perspective set out here, the recent rise of international legal norms becomes observable as a sociological phenomenon which is inseparable from more classical sociological processes, and the foundations of international norms can be directly traced to articulated forces in the fabric of national societies. Second, this article aims to show that lack of a sociological approach to international law has meant that our basic comprehension of the structure and foundations of global society remains rather underdeveloped and simplistic. It argues that international human rights law should not be seen as a normative order that reduces the power of states. Instead, the international growth of human rights can be interpreted, in many cases, as a potent element in the evolution of effective state power. If we abandon static positivist models of state power, it

\footnotetext{
${ }^{23}$ Classically, sociology was very sceptical about international law, which, in its detachment from common patterns of social action, it saw as formalistic and asocial. Famously, for instance, Weber refused to accept international law as law. See Max Weber, Wirtschaft und Gesellschaft. Grundriß der verstehenden Soziologie (Tübingen: Mohr, 1921), p. 18. See also See Eugen Ehrlich, Grundlegung der Soziologie des Rechts, $4^{\text {th }}$ edition (Berlin: Duncker und Humblot, 1989), p. 19. There have been some realist attempts to establish a sociological approach to international law. See Max Huber, Die soziologischen Grundlagen des Völkerrechts (Berlin-Grunewald: W. Rothschild, 1928); Hans J. Morgenthau, 'Positivism, Functionalism, and International Law.' The American Journal of International Law 34(2) (1940): 260-284. In the 1920s, Roscoe Pound also called for a sociological re-orientation in international law. Pound claimed that international law must deal with the 'concrete claims of concrete human beings', putting aside its conventional attempt to deduce legal norms from 'the perfect abstract state' and the 'perfect abstract man'. Quoted in Yuen-Li Liang, 'Roscoe Pound and the Science of International Law.' Tulane Law Review 22(3) (1948): 369-383; 375. However, international law is not yet an eminent object for sociological research. For a recent exception see Hauke Brunkhorst, Critical Theory of Legal Revolutions - Evolutionary Perspectives (London/New York: Continuum, 2014). Some sections on the sociology of international human rights law is now included in Moishe Hirsch, Invitation to the Sociology of International Law (Oxford: Oxford University Press, 1015).
} 
becomes clear that the global legal presumption that legislation must be proportioned to overarching human rights norms has acted, not only constitutionally to reform, but, often, greatly to augment the structural integrity (sovereignty) of national legislative actors. In particular, the rise of international human rights law can be viewed as a process that creates a normative domain in global society which allows national states to resolve, or to stabilize their reactions to, the problems of inclusion that historically played an endemically unsettling role in the formation of national political institutions. International law thus develops, not as an external normative limit on, but as an inner functional or structurebuilding precondition of, strong, inclusive, sovereign national statehood.

\section{INTERNATIONAL LAW AND CRISES OF INCLUSION}

\subsection{International law and class antagonism}

This internal structure-building role of international human rights law can be seen most strikingly in the sphere of economic inclusion. This is the social domain in which, historically, national states have been subject to the most debilitating inclusionary pressures. However, the rising intersection between national and international human rights law has led to an emphatic transformation of the state in its functions of economic inclusion.

In general terms, the formation of the modern state has been profoundly determined by the fact that, as soon as it began to assume regulatory responsibilities for a national society, it was expected to support its functions through the inclusion of highly divergent, and often acutely antagonistic, social classes. Well into the nineteenth century, the early form of the national state, visible in the core European heartlands of state construction, acted merely as a thin institutional entity, which was required to enact very simple political directives. Except for momentary acts of political repression, the early form of the modern state remained largely insensitive to even the most febrile social conflicts; in fact, society itself was barely centralized, and most social conflicts occurred at a local 
level and were subject to local authority. ${ }^{24}$ However, as it gradually penetrated more deeply into society, the emergent modern state assumed directive powers for an expanding arena of social interaction. As a result, it was obliged to mobilize support for its activities across different spheres of society, often amongst naturally hostile social groups. This was typically reflected, first, at a simple political level, through the gradual legalization of mass suffrage, which was designed, functionally, to deepen support for the state by widening the range of politically relevant actors in society. As the process of comprehensive political enfranchisement progressed, however, the social classes that the state incorporated began to channel palliative material expectations towards the public organs of government. The state was thus forced to extend its inclusionary functions beyond the classical political domain, and it was called upon to mediate between, and even to establish working settlements amongst, different social factions in order to secure its own societal foundations. Ultimately, the fact that, under conditions of early mass democracy, all social classes acquired some degree of relevance for state power meant that the modern state was obliged to demonstrate legitimacy through its ability to balance the interests of different social groups, and, in particular, to address conflicts between classes over the distribution of material goods and the regulation of conditions of industrial production. The emergent national state ultimately made its legitimacy contingent upon its capacities for resolving, or at least pacifying, deep-lying social antagonisms, and its structural stability depended on the ongoing negotiation of an equilibrium between rival collective interests. The inclusion of class conflict, in consequence, formed the primary and most fundamental cornerstone of the modern state, and the expectation of effective inclusion of hostile social groups defined the form of the modern national state more or less from birth.

States that attempted to derive legitimacy from the comprehensive absorption and mediation of class conflict were almost invariably precariously formed, and cases of acute instability resulting from such inclusion can be observed in all processes of state

\footnotetext{
${ }^{24}$ For example, as late as the 1830s, the Home Office of the UK, surely the state with the most advanced regulatory capabilities in Europe at that time, employed the grand total of twenty-nine staff. See P.P. Craig, Administrative Law (London: Sweet and Maxwell, 1983), p. 58
} 
construction. This has been widely documented in states in Latin America and Sub-Saharan Africa. In these settings, attempts at political mediation between social groups had particularly deleterious consequences for state structure. Most Latin American states which embarked on policies of expansive inclusion and palliative class mediation were simply unable to sustain their exposure to the processes of social politicization which they (in part) engendered, ${ }^{25}$ and they struggled to preserve a position of reliable autonomy and public authority, elevated above rival groups and private interactions in society. ${ }^{26}$ Similarly, during the process of decolonization in Africa, most states proclaimed legitimacy through strategies of economic interventionism and social conflict management. They attempted to sustain compliance in society through the selective allocation of economic goods, through artificially high levels of public employment and publicly funded production, and through the (often coerced) corporate integration of labour. ${ }^{27}$ However, this typically placed unmanageable burdens on states, whose regulatory capacities were already very fragile, and it usually resulted in a profound depletion of state autonomy. ${ }^{28}$

Despite the importance of such cases, however, the inclusionary pressures afflicting the state through its role as a mediator of class conflict obtained their classical expression in the processes of state construction underlying modern European societies. This was already anticipated by Karl Marx in the 1850s. Marx observed that, as it edged uncertainly

\footnotetext{
${ }^{25}$ See in this regard the theory of the politicized state set out in Douglas A. Chalmers, 'The Politicized State in Latin America' in James M. Malloy (ed), Authoritarianism and Corporatism in Latin America (Pittsburgh: University of Pittsburgh Press, 1977), pp. 23-46; 30-1, 38. On over-politicization in Argentina see Gerardo L. Munck, Authoritarianism and Democratization. Soldiers and Workers in Argentina, 1976-1983 (University Park, PA.: Pennsylvania State University Press, 1998), p. 51. On over-politicization in Chile see Remmer, 'State Change in Chile', p. 6; Faúndez, Marxism and Democracy in Chile, p. 254; Arturo Valenzuela, The Breakdown of Democratic Regimes: Chile (Baltimore: Johns Hopkins University Press, 1978), p. 33.

${ }^{26}$ Kathryn Sikkink, Ideas and Institutions. Developmentalism in Brazil and Argentina (Ithaca: Cornell University Press, 1991), p. 171.

${ }^{27}$ For expert analysis of the relation between patrimonial state privatization and corporate integration of society in the state see René Lemarchand, 'The State, the Parallel Economy, and the Changing Structure of Patronage Systems' in Donald Rothchild and Naomi Chazan (eds.), The Precarious Balance. State and Society in Africa (Boulder, CO.: Westview, 1988), pp. 149-170; 155-6. See also Thomas M. Callaghy, 'The State and the Development of Capitalism in Africa: Theoretical, Historical and Comparative Reflections' in Donald Rothchild and Naomi Chazan (eds), The Precarious Balance. State and Society in Africa (Boulder, CO.: Westview, 1988), pp. 67-99; 82; Nicolas van de Walle, 'Neopatrimonialism and Democracy in Africa, with an Illustration from Cameroon', in Jennifer Widner (ed), Economic Change and Political Liberalization in Sub-Saharan Africa (Baltimore: London, 1994), pp. 129-157; 133.

${ }^{28}$ For deeply influential commentary see Robert H. Jackson, Quasi-States: Sovereignty, International Relations, and the Third World (Cambridge: Cambridge University Press, 1990), p. 119. See also Nicolas van de Walle, African Economics and the Politics of Permanent Crisis, 1979-1999 (Cambridge: Cambridge University Press, 2001), pp. 52-4
} 
towards an early pattern of constitutional democracy, the modern state was increasingly marked by a structural contradiction - and a resultant pathology of de-legitimization which was induced by the presumption that it should include and mediate between rival social forces, whose interests could not be consensually unified. ${ }^{29}$ Most strikingly, however, this problem was intensified in Europe directly after World War I, when most states underwent an accelerated transition to mass democracy. As a result of this transition, which was usually shaped by the rapid political integration of trade unions and labour movements during the war, most European states after 1918 were forced to define their legitimacy through the integration of representatives of big business and organized labour, and to establish consensual agreements between these groups regarding the overall direction of polity, economy, and society. In many cases, this meant that states pledged themselves, as a point of incontrovertible constitutional legitimacy, to expressing a public will that was built on a material-democratic or corporatist-democratic compromise between trade unions and entrepreneurs about organization of the industrial economy. ${ }^{30}$ However, it is self-evident that, in interwar Europe, few states were equal to the inclusionary expectations that were directed towards them. In virtually all post-1918 European societies, the constitutional model of conflict palliation through corporatist democracy, which resulted from post-armistice political and economic reform, was almost immediately afflicted by very profound systemic crisis. Most states that committed themselves to corporatist-democratic experiments were incapable of preserving a balance between the adversarial, and often highly politicized, class interests which they had internalized. In most cases, within a short period of time, one group (typically the economically dominant group in the corporatist industrial system) came to utilize its position within the state to assert disproportionate influence over political-economic institutions and policy making. As a result, potent extra-political actors rapidly stripped the state of its corporate/consensual obligations and converted the state into an authoritarian (often described as fascist) instrument of economic management, strategically favouring

\footnotetext{
${ }^{29}$ Karl Marx, Der achtzehnte Brumaire des Louis Napoleon, in Karl Marx and Friedrich Engels, Werke, in 43 vols. (Berlin: Dietz, 1960), Vol. VIII, pp. 113-207.

${ }^{30}$ See my discussion in Chris Thornhill, A Sociology of Constitutions: Constitutions and State Legitimacy in HistoricalSociological Perspective (Cambridge: Cambridge University Press, 2011), Chap. 4.
} 
one privileged bloc of economic interests in society. ${ }^{31}$ In most states in interwar Europe, therefore, the corporatist-constitutionalist politicization of class interests ultimately created a situation in which state institutions forfeited their clearly public, or eminently sovereign, character, and experienced egregious inner fragmentation and reprivatization. $^{32}$

Across the most varied lines of state building, overall, few modern national states have been able to preserve a distinct public identity through the transition to wide-scale material inclusion linked to the process of mass-based state formation. A common pathological conjuncture in the rise of the modern state is that most states were expected to politicize and mollify industrial conflicts at a historical juncture before their systemic autonomy and institutional integrity had been fully consolidated. Accordingly, almost every state was at some point reduced to a condition close to systemic implosion, usually resulting in egregious re-privatization of public goods, because of its inability to secure a public balance between the divergent economic prerogatives which it internalized. In very general fashion, the politicization of class conflict gave rise to the primary crisis of inclusion which destabilized the modern national state, and often obstructed the formation of the state as an organ of sovereign social authority.

This sociological construction of the state throws distinctive light on the growth of international law, and especially international human rights law. If we observe the state as an endemically unsettled centre of social inclusion, we can identify deeply rooted processes of social formation which contribute to the promotion of international rights norms, and we can see these norms as constitutive elements of the historical structure of national societies. Distinctively, rights-based norms of international provenance often assume importance because they restrict the degree to which national state institutions are destabilized by inclusionary pressures - especially by the inclusion of class conflicts. In a number of cases, the use of international human rights for conferring legitimacy on

\footnotetext{
${ }^{31}$ For analysis of fascist Italy, accentuating these points, see Franklin Hugh Adler, Italian Industrialists from Liberalism to Fascism. The Political Development of the Industrial Bourgeoisie, 1906-1934 (Cambridge University Press, 1995), p. 155; Giulio Sapelli, Fascismo, grande industria e sindicato. Il caso di Torino 1929/1935 (Milan: Feltrinelli, 1975 ), p. 115.

${ }^{32}$ On state fragmentation as a feature of fascism see Dieter Rebentisch, Führerstaat und Verwaltung im Zweiten Weltkrieg. Verfassungsentwicklung und Verwaltungspolitik 1939-1945 (Stuttgart: Franz Steiner, 1989), p. 283; Gerhard Schulz, Die Anfänge des totalitären Maßnahmenstaates (Frankfurt am Main: Ullstein, 1974), p. 294.
} 
legislative acts has made it possible for states to isolate themselves from the disruptive conflicts, which they had previously internalized, and to preserve a certain independence towards sources of antagonism in society. Notably, this has enabled states more clearly to regulate the procedures through which they integrate material interest groups, and it has enabled political institutions to ensure that rival organizations in the economic production process remain located in more easily controllable positions: i.e. outside the structure of the state itself. In this respect, the international rise of human rights as normative formulae for defining the legitimacy of legislation has created a conjuncture in which political systems are able to heighten their general differentiation - their distinctive publicness - in relation to society as a whole. In many societies, international rights norms act as new media of state construction, which permit states to avoid, or at least to mollify, the inclusionary crises that historically eroded their foundations. In many societies, in fact, the absorption of human rights norms from the international legal order has made it possible for state institutions to approach a degree structural completion which they could not reach using purely national legal resources, and so to gain effective public sovereignty across society at large.

Important early cases of this can be found in the post-authoritarian state building which took place in Italy, West Germany, and Japan in the first wave of transnational rights consolidation following 1945. Notably, in their interwar form, these states had all suffered an acute loss of autonomy owing to their role in the resolution of class conflicts. In each case, the problem of labour integration and enforced state arbitration of industrial disputes had led to an extreme loss of authority, and to widespread infiltration of the political system by powerful private groups. ${ }^{33}$ However, one clear distinction between the authoritarian states of Europe and East Asia before 1945 and their successor states after 1945 was that the post-1945 states were based in constitutions that accorded high

\footnotetext{
${ }^{33}$ On the role of private power in weakening the Weimar Republic see Carl Böhret, Aktionen gegen die kalte Sozialisierung 1926-1930. Ein Beitrag zum Wirken ökonomischer Einflußverbände in der Weimarer Republik (Berlin: Duncker und Humblot, 1966), pp. 104, 125; Michael Grübler, Die Spitzenverbände der Wirtschaft und das erste Kabinett Brüning: Vom Ende der Großen Koalition 1929/30 bis zum Vorabend der Bankenkrise 1931 (Düsseldorf: Droste, 1982), p. 189. On Italy, see Guido Mellis, Due modelli di amministrazione tra liberalismo e fascismo. Burocrazie tradizionali e nuovi apparati (Rome: Ministro per i beni culturali, 1988), pp. 262-3. In interwar Japan, integration of labour was lower than in Germany, but it was still considerable. See Sheldon Garon, The State and Labor in Modern Japan (Berkeley: University of California Press, 1987), p. 112.
} 
prominence to international human rights law, which assigned non-derogable quality to single personal rights, and which constructed the legitimacy of legal acts (primary or statutory) through reference to a formal system of international human rights norms. ${ }^{34}$ In their domestic application, one key outcome of the application of international human rights in these polities was that rights were utilized, in part, to depoliticize class relations, and to diminish the importance of industrial conflict resolution as a main foundation for state legitimacy. In these respects, the application of international human rights norms ultimately acted dramatically to stabilize the basic political structure of these societies.

This was the case, first, because, in each of these states, the constitutional emphasis placed on personal, singular rights after 1945 meant that collective/corporate organizations lost influence, and the political standing of large-scale delegatory and sectoral bodies (i.e. trade unions, lobbies, peak associations, cartel representatives) was reduced. These bodies were partly detached from the political system, and the state began to apply law to persons, not as corporate members of integrated associations, but as single rights-entitled legal subjects, categorically situated, and performing legally relevant activities, outside its own functional structure. However, this was also the case, second, because the constitutions of these states established Constitutional Courts with strong powers to review statutes for compliance with human rights norms, including rights norms originating in international law. These courts were able to utilize human rights to impute legitimacy to laws, they were able to explain the validity of laws on socially abstracted, formal-normative grounds, and, in so doing, they alleviated national legislatures of the need to mobilize factual support for all acts of law via appeals to potent organizations in

\footnotetext{
${ }^{34}$ The defining example of this is West Germany in 1949, whose constitution (Grundgesetz) specifically derived legitimacy from an external normative domain: through its commitment to Völlkerrechtsfreundlichkeit [friendliness to international law]. In helping to draft the Grundgesetz, one leading representative of the Social Democrats, Carlo Schmid, stated that the Grundgesetz should provide for immediate domestic application of international human rights. He argued that it was vital 'to depart from the previous doctrine of international law, in which international law only addresses states, and not single individuals, so that the individual person is only bound by provisions of international law, and only obtains rights from them, when norms of international law are transformed into domestic law by national legislators': Carlo Schmid, Parlamentarischer Rat, Verhandlungen des Hauptausschusses, 18.11.1948, p. 65. Notably, the Grundgesetz also dramatically reduced expectations of social inclusion vis-à-vis organized labour, and it clearly separate trade-union activity from the state by sanctioning union rights of collective bargaining.
} 
their constituencies. ${ }^{35}$ In both these respects, human rights were activated in postauthoritarian states created after 1945 to control the boundaries between state and society, and to heighten the distinction of the political system as a whole. In the key case of interwar Germany, for example, the disruption of the political system through corporate inclusion of labour conflicts had been especially damaging, and the structural privatism caused by this had been particularly extreme. ${ }^{36}$ In the West German state founded after 1945, however, new labour legislation conferred a less strictly political character on trade unions, and it partially renounced the collectivist legal design of the interwar political economy. ${ }^{37}$ This was reflected in laws that guaranteed autonomy in collective bargaining for trade unions, placing industrial relations and wage disputes outside the immediate purview of state power. ${ }^{38}$ But the general anti-collectivist impulse of the period also gave rise to legislation restricting the power of cartels, which had previously been highly institutionalized. ${ }^{39}$ In the new West German state, moreover, the grammar of rights, supported in part by the emerging diction of international human rights law, was consciously utilized by the Constitutional Court to underwrite the state's monopoly of normative force, and the assertion of inclusionary societal control by the political system was conducted, not through economic collectivism, but in the specific, universal register of human rights. ${ }^{40}$ Under these conditions, ultimately, a state emerged in West Germany which was marked a relatively high degree of autonomy in relation to social and economic

\footnotetext{
${ }^{35}$ In West Germany, the Constitutional Court was progressively understood as an organ of state, equal in standing to the legislature and the executive. See Gerhard Leibholz, 'Einleitung: Der Status des Bundesverfassungsgerichts.' Jahrbuch des öffentlichen Rechts, Neue Folge 6 (1957): 110-221: 149-50).

${ }^{36}$ See note 33 above.

${ }^{37}$ See Jürgen P. Nautz, Die Durchsetzung der Tarifautonomie in Westdeutschland. Das Tarifvertragsgesetz vom 9. April 1949 (Frankfurt am Main: Lang, 1985), p. 45

${ }^{38}$ See Wilhelm Rütten, 'Gewerkschaften und Arbeitsrecht nach dem Zweiten Weltkrieg (1945-1950/52)' in Bernhard Diestelkamp, Zentarô Kitagawa, Josef Kreiner, Junichi Murakami, Knut Wolfgang Nörr and Nobuyoshi Toshitani (eds), Zwischen Kontinuität und Fremdbestimmung. Zum Einfluß der Besatzungsmächte auf die deutsche und japanische Rechtsordnung 1945 bis 1950 (Tübingen: Mohr 1996), pp. 149-166; 160-2.

${ }^{39}$ For the theoretical basis of this see Franz Böhm, 'Die Bedeutung der Wirtschaftsordnung für die politische Verfassung (1949)' in Ulrich Scheuner (ed), Die staatliche Einwirkung auf die Wirtschaft (Frankfurt am Main: Athenaum, 1971), pp. 85-107; 107

${ }^{40}$ For brilliant commentary see Hans Vorländer, 'Deutungsmacht - Die Macht der Verfassungsgerichtsbarkeit' in Hans Vorländer (ed.), Die Deutungsmacht der Verfassungsgerichtsbarkeit (Wiesbaden: Verlag für Sozialwissenschaften, 2006), pp. 9-36
} 
organizations. Unlike the political institutions of interwar Germany, this state was able consistently to legislate for all society, and to imprint normative unity on society in its totality, without obvious monopolization by dominant interests. ${ }^{41}$

Related important examples of the structure-building force of international human rights norms are evident in the Iberian transitions to democracy in the 1970s. The Iberian dictatorships devised by Franco and Salazar in the 1930s displayed all classical hallmarks of weak statehood: i.e. reduced options in policy making, low levels of social compliance, uneven societal control, acute private arrogation of public office. ${ }^{42}$ This weakness was caused - at least to some degree - by the fact that these states were designed on a model of corporatist economic management, in which the state mustered compliance for legislation through immediate control (part coercive, part compensatory) of class hostilities and industrial production. This was effected through the establishment of vertical syndicates, connecting state departments to productive sectors in the economy, which were used to suppress traditional trade union activities, to police potential industrial insurrection, and to provide an integral directive framework for each branch of the economy. Over time, these corporate arrangements had an intensely corrosive impact on the inner structure of the state. They led to a proliferation of judicial functions, to a constant politicization of labour conflicts, and to the extensive reliance of state agencies on open violence as a means to pacify important industrial sectors. ${ }^{43}$ Above all, these arrangements led to a reduced demarcation between state functions and economic organizations, as private economic interest groups, not uniformly compliant with declared state objectives, were able to infiltrate the state through the syndicates and other bargaining channels, and to assume control over legislative processes. ${ }^{44}$

\footnotetext{
${ }^{41}$ See the seminal ruling in the famous »Lüth-Urteil« (1958) in Entscheidungen des Bundesverfassungsgerichts, Vol. 7, 198-230.

${ }^{42}$ Richard Gunther, Public Policy in a No-Party State. Spanish Planning and Budgeting in the Twilight of the Franquist Era (Berkeley: University of California Press, 1980), p. 259.

${ }^{43}$ Raimund Beck, Das Spanische Regierungssystem unter Franco (Bochum: Brockmeyer, 1979), p. 297; Francisco J. Bastida, Jueces y Franquismo. El pensamiento del Tribunal Supremo en la Dictadura (Barcelona: Editorial Ariel, 1986), p. 185; Mónica Lanero Táboas, Una milicia de la justicia. La política judicial del franquismo (1936-1945) (Madrid: Centro de estudios constitucionales, 1996), pp. 339, 345.

${ }^{44}$ See Harry Makler, 'The Portuguese Industrial Elite and its Corporative Relations: A Study of Compartmentalism in an Authoritarian Regime.' Economic Development and Social Change 24(3) (1976): 495-526; 525; Kenneth Maxwell,
} 
In the Iberian transitions beginning in 1974, however, constitutions were founded in Portugal and Spain that gave very elevated status to international human rights, and which defined human rights as the primary source of legitimacy for national laws. Especially in transitional Spain, human rights were projected as inviolable principles to legitimize acts of law, and under the 1978 Constitution a Constitutional Court was established which subject new laws to very strict review with regard to human rights compliance. ${ }^{45}$ In both Spain and Portugal, this rise of human rights determined the emergent structure of the state in a number of different ways. At one level, the rise of human rights coincided with a thorough re-structuring of the syndicalist system of economic management constructed by Franco and Salazar, as rights of contractual freedom were guaranteed to trade unions, which meant that the syndicalist system was abandoned, and trade-union activities were relocated - to a large degree - to positions outside the political system. The primary result of this was that the traditional deep intersection between the state and powerful bargaining associations was loosened, and internal channels of interaction between state and economic interest groups were replaced by a more horizontal set of linkages: trade unions, political parties, and business lobbies resumed independent activities outside the state, and they began to negotiate with state departments from external positions. This meant that legislation could be conducted without comprehensive inclusion of strictly extrapolitical organizations, and the degree of political mobilization required for law making was reduced. This also meant that the state was less vulnerable to disruption through labour conflicts, it was able to situate such conflicts outside its own structure, and, in this respect too, it was able to produce legislation to address economic interactions and organizations without immediate inner volatility. ${ }^{46}$ In Spain, in particular, the

\footnotetext{
'Regime Overthrow and the Prospects for Democratic Transition in Portugal', in Guillermo O'Donnell, Philippe Schmitter, Philippe and Laurence Whitehead (eds), Transitions from Authoritarian Rule. Southern Europe (Baltimore: Johns Hopkins University Press, 1986), pp. 109-137; 132; Angel Rodrigez Diaz, Transicion politica y consolidacion constitucional de los partidos politicos (Madrid: Centro des Estudios Constitucionales, 1989), p. 223.

${ }^{45}$ Articles 10.2 and 96.1 of the 1978 Constitution of Spain gave very high standing to international treaties and resultant agreements regarding human rights. This constitution was designed to give higher protection to rights than existing international law itself. See Xavier Pons Rafols, 'Constitución española y principios del derecho internacional', in Josep María Castellà Andreu (ed), La Constitución y el ordenamiento jurídico (Barcelona: Atelier, 2005), pp. 75-93.

${ }^{46}$ Manuel Redero San Román and Tomás Pérez Delgado, 'Sindicalismo y transición política en España.' Ayer 15 (1994): 189-222; 190, 210.
} 
establishment of a Constitutional Court conducting rights-based review of statutes and administrative acts meant that access to law-making power was systematically reserved for formally designated actors, and the constitutional order as a whole acquired sharper definition and public differentiation. ${ }^{47}$ Overall, the fact that during the democratic transition formal rights replaced coerced material inclusion as the basis of the state led to a rapid and measureable increase in the structural autonomy of the political system, which became visible in increased policy-making options, augmented flexibility in legislation, and extended judicial reach into society. ${ }^{48}$ In each respect, above all, the fact that state institutions defined their legitimacy through human rights clarified the boundaries between state and society, and it simplified the channels through which state and society could conduct necessary interactions. This increase in its public distinction clearly heightened the inclusionary force of the state as a whole.

We can see further evidence of this inclusionary, structure-building effect of international human rights in more recent processes of democratic state formation - for example, in Sub-Saharan Africa.

In many societies in Southern Africa, post-colonial statehood was based on the triadic foundation of one-party rule, one-nation ideology, and the extensive (at times, highly coercive) corporatist integration of labour organizations in the political system. As the flagship post-colonial state in Africa, Ghana under Nkrumah is perhaps the key example in this respect. In post-independence Ghana, the polity was constructed around an inflated public sector and a broad state periphery, and it was increasingly dominated, after 1960, by a one-party executive, in which corruption and patrimony were rife. At the core of this polity was a system of national industrial co-ordination and planned economic management (based in state industries) and a corporatist model for labour administration. Immediately after independence, for example, Nkrumah's administration introduced a raft of laws that established compulsory arbitration in labour disputes, created official unions,

\footnotetext{
${ }^{47}$ Enrique Guillén López, 'Judicial Review in Spain: The Constitutional Court.' Loyola of Los Angeles Law Review 41 (2007-2008): 529-562; 540.

${ }^{48}$ Notably, after 1978, the Spanish state was able to transpose private organizations traditionally usurping a portion of state power into locations positioned outside the state. See J. Martinez-Alier and Jordi Roca, 'Spain after Franco: From Corporatist Ideology to Corporatist Reality.' International Journal of Political Economy 17(4) (1987): 56-87; 74.
} 
and made union activities subject to state directives. ${ }^{49}$ Industrial legislation of the early 1960s then implemented mechanisms for setting mandatory wage levels, consolidating official control of unions, and co-ordinating union activity through the party executive. ${ }^{50}$

In much of Africa, moreover, post-colonial state formation created states that were only very weakly differentiated from society, and which struggled to project themselves as solid inclusionary centres of social order. This was partly caused by the evident lack of cohesion between externally imposed centralized political institutions and the historically given, highly localized societal structure. ${ }^{51}$ However, it was also caused by corporate experiments in the public economy. In Ghana, for example, the model of corporate economic integration quickly triggered high levels of privatization in the political system, state industries and controlled unions were used to provide sinecures for allies of the government, ${ }^{52}$ and public offices, resources, and services were commonly transacted in the form of privilege, spoils, and guarantees for material security. ${ }^{53}$ At the latest by the early 1970s, the Ghanaian political system was incapable of sustaining its interventionist functions, ${ }^{54}$ and, lacking the capacity to steer the economy, it showed extreme reliance on patrimonialism and corruption for societal support. The deep interpenetration between the state and the economy gave rise to a political system that suffered from very weak differentiation, from high intersection between public office and private prerogative, from restricted functional autonomy (especially in relation to its core economic objectives), and,

\footnotetext{
${ }^{49}$ See Lester N. Trachtman, 'The Labor Movement of Ghana: A Study in Political Unionism.' Economic Development and Cultural Change 10(2/1) (1962): 183-200; 185.

${ }^{50}$ Douglas Rimmer, 'The New Industrial Relations in Ghana.' Industrial and Labour Relations Review 14(2) (1961): 206226; 215, 216, 223; Rolf Berritsen, 'The Evolution of the Ghana Trades Union Congress under the Convention Peoples Party: Towards Re-Interpretation.' Transactions of the Historical Society of Ghana 13(2) (1972): 229-244; 237.

${ }^{51}$ See pp. XXX below

${ }^{52}$ Robert H. Bates, Markets and States in Tropical Africa. The Political Basis of Agricultural Politics (Berkeley: University of California Press, 1981), p. 104

${ }^{53}$ See S. N. Sangmpam, 'Neither Soft nor Dead: The African State is Alive and Well.' African Studies Review 36(2) (1993): 73-94; 92; Jonathan H. Frimpong-Ansah, The Vampire State in Africa. The Political Economy of Decline in Ghana (London: James Currey, 1991), p. 98.

${ }^{54}$ See Antoinette Handley, Business and the State in Africa. Economic Policy-Making in the Neo-Liberal Era (Cambridge: Cambridge University Press, 2008), p. 158.
} 
as a result, from constant loss of legitimacy. ${ }^{55}$ Different analysts have argued that at this time the Ghanaian state experienced comprehensive loss of capacity and general 'power deflation', it was defined by 'anarchic pillage of public resources', 56 and it was - as a whole - scarcely recognizable as an aggregate of public institutions. ${ }^{57}$ Similarly, one observer has described Ghana at this time as 'paradigmatic "soft" state', existing primarily, not as a functioning political entity, but as a rather fictitious category of international law. ${ }^{58}$ Ghana is cited here as an extreme case of state collapse through inflationary pressures of inclusion. Yet, similar tendencies towards the inner privatization of the state can be observed in most African states, even in those, such as Kenya, in which forcible economic control played a less important ideological role. ${ }^{59}$

In most cases, however, the post-independence design of African states ultimately underwent a two-stage process of reconstruction, through which the state's relation to economic organizations was fundamentally re-defined. Typically, this process was linked to a change in the status of human rights norms and it reflected the growing interaction between national and international law. In most African societies, the rise of human rights as elements of state authority impacted deeply on the position of the state in society as a whole, and on the ability of the state to absorb inclusionary societal pressures.

In most of Southern Africa, the first stage of this reform process began in the 1980s with the introduction of a series of economic reform policies designed to consolidate a regime of single monetary rights in different national societies. These policies, known as Structural Adjustment Programmes (SAPs), were initiated by the International Monetary Fund (IMF), and they were implemented in many developing societies - not only in Africa, but also in Latin America. The objectives of these policies, which are commonly seen as

\footnotetext{
${ }^{55}$ See Robert H. Price, Society and Bureaucracy in Contemporary Ghana (Berkeley: University of California Press, 1975), p. 40.

${ }^{56}$ Chazan, An Anatomy of Ghanaian Politics, p. 337; Douglas Rimmer, Staying Poor. Ghana's Political Economy 19501990 (Oxford: Pergamon, 2002), pp. 223

${ }^{57}$ Richard Jeffries, 'The State, Structural Adjustment and Good Government in Africa.' The Journal of Commonwealth and Comparative Politics 31(1) (1993): 2035; 24

58 Jeffrey Herbst, The Politics of Reform in Ghana, 1982-1991 (Berkeley: University of California Press, 1993$)$, p. 4.

${ }^{59}$ Merilee S. Grindle, Challenging the State: Crisis and Innovation in Latin America and Africa (Cambridge: Cambridge University Press, 1996), p. 79. Grindle argues that by the 1980s the 'authoritativeness and legitimacy' of the Kenyan state were 'under siege' (ibid p. 184).
} 
defining expressions of the (so-called) neo-liberal economic climate of the 1980s, were to promote international economic opening, to reduce domestic and international debt, to lower public-sector salaries and expenditure, and generally to restrict state intervention in economic practices. ${ }^{60}$ Subsequently, in much of Southern Africa, the economic reforms of the 1980s were followed in the 1990s by extensive political reforms, in which new quasidemocratic constitutions were established. In many cases, these constitutions contained provisions that increasingly (albeit incompletely) tied national legal systems into international human rights conventions, and aligned domestic law to international norms. Most new African constitutions accorded particular protection to international human rights norms and high standing to national judicial bodies, which obtained unprecedented importance in society. ${ }^{61}$ In some extreme cases, judicial bodies, applying international law, effectively became parallel or supplementary legislators, and functions traditionally allocated to legislators were transferred to judicial institutions. ${ }^{62}$

This two-stage reform process typically instilled a new pattern of state formation in African society. This matter, of course, contains a number of very sensitive questions, and in discussing these questions discrimination is imperative. Self-evidently, it would be absurd to argue that the liberalizing policies of the 1980s meant that state institutions were consistently strengthened across all of Southern Africa. It is often argued, in fact, that the converse was the case. It has been asserted, surely plausibly, that the SAPs induced a rise in lower-level patrimonialism in national political systems, as minor civil servants, finding their reduced salaries insufficient to cover living costs, made extensive use of public offices to engage in market practices. Similarly, it is argued that the SAPs meant that leaders of weak states became more inclined to accept informal material aid from external

\footnotetext{
${ }^{60}$ See for general discussion Catherine M. Conaghan and James M. Malloy, Democracy and Neoliberalism in the Central Andes (Pittsburgh: University of Pittsburgh Press, 1994), p. 99; Robert Lensink, Strucural Adjustment in SubSaharan Africa (London: Longman, 1996), pp.1-2; Julius E. Nyang'oro, 'The Evolving Role of the African State under Structural Adjustment' in Julius E. Nyang'oro and Timothy Shaw (eds), Beyond Structural Adjustment in Africa. The Political Economy of Sustainable and Democratic Development (New York: Praeger, 1992), pp. 11-28; 12, 14.

${ }^{61}$ Representing a very large body of research on this, see Babacar Kanté, 'La production d'un nouveau constitutionalisme en Afrique: Internationalisation et regionalisation du droit constitutionnel' in Jan Abbink and Mirjam de Bruijn (eds), Land, Law and Politics in Africa. Mediating Conflict and Reshaping the State (Leiden: Brill, 2011), pp. 240-257; 249.

${ }^{62}$ Brice Dickson, 'Protecting Human Rights through a Constitutional Court: The Case of South Africa.' Fordham Law Review 66 (1997): 531-566; 566.
} 
actors (i.e. foreign investors), usually in return for guaranteed privilege in the domestic economy (especially access to resources). ${ }^{63}$ On these grounds, it is widely concluded that economic liberalization in the 1980s directly exacerbated already prevalent tendencies towards privatism and patrimonialism in African statehood, and it had a deeply 'negative impact on state capacity'. ${ }^{64}$ Moreover, it is well documented that in many African societies the policies of constitutional democratization in the 1990s were flanked by a diffusion of formerly public functions throughout society, so that the ability of the political system to reach into society came to depend on co-operation between the state and more informal agencies, many rooted in the private arena. ${ }^{65}$ Clearly, in sum, it cannot be unquestioningly presumed that either stage of the reform process brought direct structural advantages to affected political systems. Despite this, however, the incremental institution of a system of human rights, sustained in part by international law, performed visible structure-building functions for societies in Southern Africa that experienced structural reform processes. To some degree, the rise of human rights and judicial institutions transposed the political system onto new foundations, and it brought a new inclusionary distinction to public order. $^{66}$

Among other outcomes, first, the monetary reform policies of the 1980 s greatly altered the strategies used by states for securing control and legitimacy through society, and they led to a deep change in the social bases of statehood. In particular, the introduction of domestic austerity policies through the SAPs reduced the extent to which the state could integrate and placate economic organizations by means of material payoffs, and the capacity of the state for mediating between rival economic groups was curtailed. This led to a deprioritization of economic conflict management as a source of

\footnotetext{
${ }^{63}$ On these points see William Reno, 'The Privatisation of Sovereignty and the Survival of Weak States' in Béatrice Hibou (ed), Privatising the State (London: Hurst, 1999), pp. 95-120; 102, 112.

${ }^{64}$ See for example Van de Walle, African Economics, p. 11; James Ferguson, Global Shadows. Africa in the Neoliberal World Order (Durham, NC: Duke University Press, 2006), pp. 11, 35, 100.

${ }^{65}$ Ferguson, Global Shadows, p. 204.

${ }^{66}$ Accordingly, even some of the most vehement critics of this process note that the reconfiguration of relations between state and society gave rise, not to a weakening, but rather to a reconfiguring of statehood, which does not necessarily diminish state capacity. See Béatrice Hibou, 'From Privatising the Economy to Privatising the State: An Analysis of the Continual Formation of the State' in Béatrice Hibou (ed), Privatising the State (London: Hurst, 1999), pp. 1-46; 17.
} 
legitimacy, and it meant that states could less easily secure legitimacy by patrimonial practices and private transactions. ${ }^{67}$ In this respect, the first stage of the reforms meant that states were required to define and project their legitimacy in new, revised categories. Moreover, if we focus on the strictly formal and procedural dimensions of the political system, we can see, in some cases, that the implementation of international human rights norms during the political stage of the reforms in the 1990s allowed some African states to react to altered requirements for legitimacy triggered by the previous monetary reforms, and - however imperfectly - human rights promoted the growth of political structures, able to fill the legitimatory gap left through the partial retreat of the patrimonial state. At one level, most obviously, the rising power of the judicial branch that accompanied the constitutional reforms of the 1990s, impelled by heightened international presumptions in favour of human rights, merely reflected a surrogate pattern of institution building, in which responsibility for public order was devolved to courts because, due to lack of resources, other organs of state were not equipped to perform designated regulatory obligations. To this degree, the assimilation of human rights norms in African states merely acted to stabilize a fragile and vestigial legal structure, in which it was possible to conduct some residual functions, in the vacuum left by failed corporatism and IMF-dictated adjustment policies. ${ }^{68}$ At the same time, however, judicial actors, applying human rights norms, also promoted an alternative, substantially distinct, pattern of political system building in Southern Africa, and they tentatively began to construct a model of statehood adapted to societies marked by the failure of patrimonialism and material inclusion as a source of structural stabilization.

If we again take the classical case of Ghana, for example, we can see that the first (monetary/economic) stage in the reform process (the SAPs in the 1980s) acted to depoliticize economic management, and to reduce the significance of

\footnotetext{
${ }^{67}$ See generally van de Walle, African Economics, p. 157; Timothy Shaw, Reformism and Revisionism in Africa's Political Economy in the 1990s (New York: St Martin's Press, 1993), p. 165.

${ }^{68}$ This point is implied in Mirna E. Adjami, 'African Courts, International Law, and Comparative Case Law', p. 104
} 
corporatist/clientelist patterns of inclusion as foundations for state legitimacy. ${ }^{69}$ The early stage of the reforms substantially cut the volume of offices sustained by the state, it eroded - in part - those institutions of the state focused on central economic coordination and growth stimulation, and it weakened the ability of the state to command legitimacy by patrimonial means. However, in the second (political/constitutional) stage of the reforms in the 1990s, a new constitution was introduced that ascribed high importance to civil and political rights, and which placed greatly increased emphasis on judicial power. ${ }^{70}$ To be sure, the new Constitution did not create an open door for international law. Even under the new constitution, Ghana still remained a formally dualist state. However, Arts 40 and 37 gave recognition to international law, at the inter-state and at the domestic level. In early leading cases, further, the Supreme Court stated that the African Charter on Human and Peoples' Rights could be invoked without formal incorporation, ${ }^{71}$ and leading judges increasingly assimilated international human rights norms to promote an objective purposive interpretation of the constitution. Importantly, then, the resultant growth of rights as principles of legal validity made it possible for the state to distil a new form of legitimacy for its functions, and it was able to presume reserves of legitimacy for its laws that were not determined solely - or even primarily - by its functions of economic integration and conflictual control. If the first stage of reform reduced the patrimonial powers of the state, therefore, the second stage established a normative diction in which the state could gradually redesign its legitimacy as a more socially differentiated, inclusionary resource. Incrementally, the fact that the state could express (at least part of) its legitimacy through reference to human rights enabled it to engage with private groups in a more measured and internally controlled manner, focusing state functions on a more strictly delineated sphere of activity, and in some respects ensuring greater autonomy both for the state and for the organizations (i.e. trade unions) traditionally integrated

\footnotetext{
${ }^{69}$ See Daniel Green, 'Ghana: Structural Adjustment and State (Re)Formation' in Leonardo A. Villalón and Philip A. Huxtable (eds), The African State at a Critical Juncture. Between Disintegration and Reconfiguration (Boulder: Lynne Rienner, 1998), pp. 185-212; 189.

${ }^{70}$ See Seth Yeboa Bimpong-Buta, The Role of the Supreme Court in the Development of Constitutional Law in Ghana, University of South Africa, PhD Dissertation (2005), p. 131.

${ }^{71}$ See New Patriotic Party $v$ Inspector-General Of Police [1993-94] 2 GLR 459 (SC)
} 
within the state. ${ }^{72}$ Moreover, the fact that the state was able to refer to human rights as sources of legitimacy meant that the state executive could, in part at least, project a personality that was distinct from specific physical agents and specific material prerogatives. ${ }^{73}$ Ultimately, this had a pervasive democratizing effect on state institutions, as it meant that executive authority acquired independent legitimacy, and it could however imperfectly - be rotated between different parties (between government and opposition)..$^{74}$ In both respects, the formal autonomy of the Ghanaian state was visibly augmented by its switch from corporatist material inclusion to singular human rights as the basis of legitimacy. In this case, international human rights norms clearly contributed in important fashion to a structure-building process. They did this in particular because they reduced inclusionary pressures caused by historically ramped expectations in respect of labour integration, politicization of labour disputes, and material placation of corporate parties, and they progressively extracted the constitutional form of the state from the privatistic relations in which it had traditionally been embedded. In these distinct respects, the growth of rights-based judicial power served as a new mode of political system building, and it helped to raise the autonomy of the state in an environment afflicted by deep depletion of political structure.

Across all different lines of state building, however, surely the most illuminating example of the structure-building function of international human rights can be found in Argentina - notably, during the post-military transition under Alfonsín, starting in 1983. Historically, the inclusion of class conflict was an intensely polarizing and deeply destabilizing question in Argentine society. Notably, in 1949, Perón created a constitution committed to extensive corporatist social objectives, entailing high levels of labour integration and high levels of income distribution. After Perón, the Argentine political system remained insurmountably polarized along the deep fissure between Peronists, who

\footnotetext{
${ }^{72}$ See Piet Konings, 'Structural Adjustment and Trade Unions in Africa. The Case of Ghana' in Alex E. Fernandez Jilberto and Marieke Riethof (eds), Labour Relations in Development (London: Routledge, 2002), pp. 311-336; 333; Richard Sandbrook and Jay Oelbaum, 'Reforming Dysfunctional Institutions through Democratisation? Reflections on Ghana.' The Journal of Modern Africa Studies 35(4) (1997): 603-646; 635; Green, 'Ghana: Structural Adjustment and State (Re)Formation', p. 209

${ }^{73}$ Close to this view is Grindle, Challenging the State, p. 12.

${ }^{74}$ Until the 1990s, powers of government in Africa were almost invariably rotated by means of military coup.
} 
favoured (albeit often very coercive) corporatist labour integration, and anti-Peronists, who promoted a more exclusionary system of corporatism and economic management, centred on repressive anti-union legislation. ${ }^{75}$ This polarization led repeatedly to extreme shifts in the structure of government. It meant that control of the political system was usually transferred, often violently and invariably without democratic procedure, from groups favouring comprehensive integration of labour in the state to groups favouring forcible repression of the labour movement. It also meant that, once one faction had obtained control of the state, this faction tended to treat the state as an instrument for securing group privileges for one class, so that the political system as a whole was hollowed out and privatized by patrimonial rent seekers. Traditionally, the Argentinean political system possessed a very low degree of autonomy in its relation towards rival factions in the industrial economy, and different social groups tried openly to monopolize state resources in order to secure protection for select material interests. Overall, the volatility attached to class conflict created a fragile and socially porous political system, which struggled, for decades, to exercise sovereign power across society. During the Argentine transition, however, Alfonsín strategically steered a course between the extreme points in the cleavages caused of social polarization. Invoking the authority of international human rights organizations and the newly founded Inter-American Court of Human Rights (IACtHR), he utilized international human rights as key normative elements in a strategy of ex-nihilo structure building and systemic formation, designed to elevate the public distinction of the state, and to weaken the internally corrosive impact of societal polarization on the political system.

Distinctively, from the outset, Alfonsín employed international human rights norms as a general vocabulary of legitimacy for the democratic regime which he established, and he derived basic authority for governance from international courts and from the

\footnotetext{
${ }^{75}$ Representing a huge volume of literature on this point, see the claim that both factions viewed politics in 'zero-sum terms' in Edward C. Epstein, 'Labor, Populism and Hegemonic Crisis in Argentina' in Edward C. Epstein (ed), Labor Autonomy and the State in Latin America (Boston: Unwin Hyman, 1989), pp. 13-38; 14. On the coercive aspects of Perón's labour policies (prohibition of rival labour parties, monopolization of central union councils), see Samuel L. Baily, Labor, Nationalism, and Politics in Argentina (New Jersey: Rutgers University Press, 1967), pp. 102-16.
} 
programmes of international human rights organizations. ${ }^{76}$ However, this use of human rights was conceived, more specifically, as a governmental technique with implications for labour regulation. Quite manifestly, Alfonsín did not pursue anti-labour policies, and his policies were not strictly anti-corporatist. Even under Menem, corporatist industrial management was not eliminated in Argentina. However, Alfonsín used rights to downplay the symbolic importance of labour integration as a source of democratic legitimacy, to depoliticize trade unionism, and to detach the state and its legitimacy from functions of corporate mediation. ${ }^{77}$ Tellingly, constitutional advisors to the early Alfonsín government expressly advocated the promotion of a constitutional order based strictly in single subjective (not group-based) rights, and they sought to introduce single rights as a basic constitutional grammar because this offered a mechanism for organizing democratic government whilst also protecting the state from excessive coalescence with private/economic organizations. ${ }^{78}$ Accordingly, Alfonsín's first planned legislative act (Ley de Reordenamiento Sindical, 1983/84) was conceived as an instrument to weaken the corporatist structure of trade union organization, to impose a pattern of single rights holding through society, and to separate units of economic organization from the state itself. ${ }^{79}$ This laws eventually blocked in its passage through senate. Nonetheless, subsequent legislation, albeit diluted, was also focused in disarticulating trade unions from the state, and securing the state against the collective conflicts that had traditionally undermined its independence. ${ }^{80}$ Ultimately, although he fell short of his goals the de-

\footnotetext{
${ }^{76}$ See generally Alison Brysk, The Politics of Human Rights in Argentina. Protest, Change, and Democratization (Stanford: Stanford University Press, 1994), pp. 95, 107; Ellen L. Lutz and Kathryn Sikkink, 'International Human Rights Law and Practice in Latin America.' International Organization 54(3) (2000): 633-659.

${ }_{77}$ Munck, Authoritarianism and Democratization, p. 155; Maria Lorena Cook, The Politics of Labor Reform in Latin America. Between Flexibility and Rights (University Park, PA.: Pennsylvania State University Press, 2007), p. 64

${ }^{78}$ Carlos Santiago Nino, 'Transition to Democracy, Corporatism and Constitutional Reform in Latin America.' University of Miami Law Review 44 (1989): 129-164; 154.

${ }^{79}$ See Marcelo Luis Acuña, Alfonsín y el poder economico. Elk fracas de la concertción y los pactos corporativos entre 1983 y 1989 (Buenos Aries: Corregidor, 1995), pp. 391, 402; Viviana Patroni, 'The Decline and Fall of Corporatism? Labour Legislation Reform in Mexico and Argentina during the 1990s.' Canadian Journal of Political Science 34(2) (2001): 249-274; 268; Ricardo Gaudio and Héctor Domeniconi, 'Las primeras elecciones sindicales en la transición democrática.' Desarrollo Económico 26(103) (1986): 423-454; 427.

${ }^{80}$ In support see Enrique Peruzzotti, 'The Nature of the New Argentine Democracy. The Delegative Democracy Argument Revisited.' Journal of Latin American Studies 33(1) (2001): 133-155; 142, 145 . Close to my position,
} 
emphasis of class in Argentina under Alfonsín broke the debilitating polarization of Argentine politics around the two rival traditional variants on corporatist ideology (i.e. Peronist, or inclusionary-corporatist and anti-Peronist, or exclusionary-corporatist models of statehood). ${ }^{81}$ After the 1980s, Argentine trade unions began to renegotiate the terms of their engagement with the political system. Although many elements of political corporatism remained intact, trade unions assumed an increasing independent role. They were required to establish collective bargains in more localized fashion, ${ }^{82}$ as organs standing outside the fabric of the state, which meant that economic legislation could be introduced without the inevitably unsettling politicization of labour conflicts within the political system. ${ }^{83}$ As a result of this, gradually, the policy-making options of the state increased, the transparent determination of policies by influential collective actors was restricted, and a political system evolved which showed remarkable autonomy even in the face of at times extreme economic crisis.

These examples of modern state building exemplify ways in which different states have been able to utilize human rights norms, borrowed in part from international law, as principles through which they reduce the political intensity of material inclusion, and through which, as a result, they harden their distinction, differentiation and specific autonomy in relation to organized societal interests. On one hand, the reference to human rights has meant that states can provide simple and already authorized justifications for single laws, and they can add legitimacy to their legislative acts (either founding or statutory) by extracting norms from an international arena, whose validity is to some degree withdrawn from intense external contest - or even formally depoliticized. On the other hand, the reference to human rights has meant that states can produce legitimacy for laws without endless absorption of corporatist interest organizations, and without the

\footnotetext{
Peruzzotti sees the process of 'constitutionalization' in Argentina as expressed through a growing 'institutional differentiation between state and society', induced by the 'emergence of rights-oriented politics' (148).

${ }^{81}$ See Ranis, Argentine Workers, pp. 54, 61.

${ }^{82}$ M. Victoria Murillo, 'La adaptación del sindicalismo argentino a las reformas de Mercado en la primera presidencia de Menem.' Desarrolo Económico 37(147) (1997): 419-446; 431, 440.

${ }^{83}$ For analysis of changes in the status of the Confederación General de Trabajo under Kirchner see Christopher Wylde, 'State, Society and Markets in Argentina: The Political Economy of Neodesarollismo under Néstor Kirchner, 20032007.' Bulletin of Latin American Research 30(4) (2011): 436-452; 442.
} 
need to declare the concrete and ongoing mediation of industrial conflict a primary basis of legitimacy for single laws. In most societies, it was only through the rise of international human rights norms that states were able to acquire a principle of legitimacy for their functions that was not dependent on reconciliation of class divisions. On both counts, the fact that states can deploy human rights as a primary source of legitimacy for legal acts has brought an exponential simplification of law-making procedures within the state apparatus. In most cases, this has led to a deep reduction in the political controversy attached to state functions, it has diminished the volume of conflict in society that needed to be channelled towards the state, and it has created a formula of legitimacy which state institutions can utilize to authorize laws while holding themselves at a level of controlled differentiation towards external actors and external conflicts. In many instances, further, this had led to an exponential stabilization of state structure, and it had brought a significant rise in state autonomy or in the effective sovereignty of national states.

In these respects, the transnational rise of human rights has played a key role in actually constructing states as states in the genuine sense of the word: that is, as inclusionary public orders, at least partly demarcated against private organizations, and able to legislate in reasonably self-authorizing and evenly inclusive fashion through society. The key to this is that international human rights norms, insofar as they are applied to authorize legislation, make it possible for the national political system to presuppose a quantum of legitimacy for acts of legislation which the political system of itself is not required to produce. The use of human rights to support legislation means that states can construct legitimacy for legislation within a pre-formed legal order: without the need to manufacture legitimacy through the concrete resolution of conflict between actors located outside its own structure. In consequence, although typically derived from an international legal domain, human rights, paradoxically, have assumed their greatest significance as internalistic normative elements in the national political system. Through this internalistic quality, they reduce the dependence of the political system on external sources of legitimacy, they counteract the politicized centration of all material conflicts around the state, they diminish the state's structural intersection with private actors, and they assume 
a crucial role in preserving the formal differentiation and effective autonomy (sovereignty) of the political system in different national societies.

\subsection{International human rights law and local/ethnic divisions}

The structure-building force of international human rights norms can also be seen in a second domain, in which the formation of modern national states has been impeded by acute inclusionary pressures. In this case, inclusionary pressures result from the fact that most states, at different points in their evolution, have been expected to include, and acutely to politicize, conflicts arising from regionally localized and at times multi-ethnic, multi-centric, social structures: that is, conflicts between centre and periphery.

Across different modern societies, the centre/periphery division has typically found expression in two quite distinct ways. On one hand, this conflict has obtained distinctive expression in uncertainly centralized legal/political systems, where it is normally reflected in the assertion of partial autonomy by local elites and privileged actors. This is typically a feature of geographically extensive societies (e.g. China, Russia, but also, until the 1960s, the USA), in which state authority has often only been sustainable through the informal interlocking of national government and local elite co-ordinators. On the other hand, this conflict has gained expression in societies whose political institutions are results of postcolonial patterns of state building, and in such contexts it is normally reflected in more extreme ethnic centrifugalism. In many instances of post-colonial state formation, national state institutions still remain only precariously settled above society, often existing alongside alternative modes of governance, alternative sources of authority, and alternative conceptions of legality, all of which are commonly coloured by lateral ethnic loyalties. ${ }^{84}$ In many Latin American and African societies, notably, the formal legal/political system has been unable to incorporate different local, ethnic and tribal groups, or in many cases, even to pierce local, customary, or tribal law. ${ }^{85}$ In some of these societies, of course,

\footnotetext{
${ }^{84}$ See Christopher Clapham, 'Degrees of Statehood.' Review of International Studies 24(2) (1998): 143-157; 154, 157; Christopher Clapham and Carl G. Rosberg, 'Sovereignty and Underdevelopment: Juridical Statehood in the African Crisis.' The Journal of Modern African Studies 24(1) (1986): 1-31; 1, 11; Jeffrey Herbst, States and Power in Africa. Comparative Lessons in Authority and Control (Princeton: Princeton University Press, 2000), p. 55.

${ }^{85}$ Pierre Englebert, State Legitimacy and Development in Africa (Boulder: Lynne Rienner, 2000), p. 98
} 
the effective legal and political sovereignty of the state has often - even very recently been exposed to unbearable centrifugal strain, and the extent to which society is evenly constructed around identifiable state-like institutions remains a matter for debate. In such societies, the political system often lacks clear features of statehood (firm territoriality, regular judicial and fiscal authority, perceived legitimacy as a primary pillar of societal order), ${ }^{86}$ and the state merely acts as one organization amidst a range of governmental actors, many of which have peripheral or ethnic foundations in society. ${ }^{87}$ In many cases, most especially in Southern Africa, government is widely conducted in concentric manner: that is, through informal linkage between central government and private or regional elites, in which traditional authorities and local centres of power act both to control particular areas and to mediate, via clientelistic relations, between localities and the central state. ${ }^{88}$ In such settings, the asymmetry between a relatively uniform legal/political order, based around centralized national institutions, and the factually existing structure of society, characterized by extreme localism and the persistence of private or customary authority, has presented an insurmountable obstacle to the emergence of consistent inclusive state authority. ${ }^{89}$ In particular, it has obstructed - and still continues to obstruct the differentiation of a uniform legal/political system, able autonomously to integrate and to legislate over different exchanges in society.

Like cases of extreme class conflict, the typical outcome of the state's exposure to pressures of peripheral inclusion is that the state experiences a privatization of public resources, which, in turn, leads to a partial dilution of the state's autonomy and effective

\footnotetext{
${ }^{86}$ Colombia is the clearest example of this in Latin America. See Paul Oquist, Violence, Conflict and Politics in Colombia (New York: Academic Press, 1980), p. 165; Frank Stafford and Mark Palacios, Colombia. Fragmented Land. Divided Society (Cambridge: Cambridge University Press, 2002), p. 298. On African states generally, see Crawford Young, 'The Colonial State and Post-Colonial Crisis' in Prosser Gifford and Wm. Roger Louis (eds.), Decolonization and African Independence. The Transfers of Power, 1960-1980 (New Haven: Yale University Press, 1988), pp. 1-32; 5.

${ }^{87}$ See Englebert, State Legitimacy, p. 74; Obiora Chinedu Okafor, Re-Defining Legitimate Statehood. International Law and State Fragmentation in Africa (The Hague: Martinus Nijhoff, 2000), pp. 30, 39; Crawford Young, 'The End of the Post-Colonial State in Africa? Reflections on Changing African Political Dynamics.' African Affairs 103 (2004): 23-49; 29; Lemarchand, 'The State, the Parallel Economy, and the Changing Structure of Patronage', p. 161.

${ }^{88}$ Trutz von Trotha, 'Die Zukunft liegt in Afrika. Vom Verfall des Staates, von der Vorherrschaft der konzentrischen Ordnung, und vom Aufstieg der Parastaatlichkeit.' Leviathan 28(2) (2000): 253-279; 266, 271; Callaghy, The StateSociety Struggle, pp. 96, 336-7

${ }^{89}$ See excellent analysis in Michael Bratton and Eric C. C. Chang, 'State Building and Democratization in Sub-Saharan Africa.' Comparative Political Studies 39 (2006): 1059-1083; 1068.
} 
sovereignty. This is manifested in different ways. In many large post-authoritarian societies (notably China and Russia), problems of peripheral inclusion are usually accompanied by the survival of embedded private power in different localities. This often means that the state is only able to utilize power through personalized co-operation, informal bargaining, and (in extreme cases) spoils sharing between accredited office holders within the state and influential private elites outside, or in the margins of, the state, which sometimes represent a specific ethnic affiliation. ${ }^{90}$ In other cases, for example in many Latin American societies, central state power suffers chronic fragmentation as it encounters 'peripheral power loci': that is, regions and localities, in which effective power structures are partly closed against the state by bearers of private/patrimonial or personalistic authority. ${ }^{91}$ However, privatistic depletion of state structure resulting from conflict over peripheral inclusion is particularly acute and widespread in Sub-Saharan Africa. In many Southern African societies, the essential political structure of society is defined by the fact that the state has not been able fully to incorporate different peripheral factions, that its inclusionary hold on different ethnic groups is variable, sporadic, and highly politicized, ${ }^{92}$ and that - as a consequence - it lacks deep foundations of legitimacy. ${ }^{93}$ In many such cases, the state is required to resort to distribution $f$ goods to local or ethnic groups in order to compensate for its lack of evenly inclusive legitimacy. Where this occurs, the need to accommodate rival peripheral groups typically leads to an expansion of the state, as the state is obliged to generate new offices and resources to promote peripheral inclusion, and to placate the rival claims of distinct populations. ${ }^{94}$ Where this occurs, however, the state usually lacks resources to secure cohesive motivations for compliance across society, and its expansionary functions form a veneer for a factual condition of endemic state diffusion.

\footnotetext{
${ }^{90}$ See note 105 below

${ }^{91}$ Guillermo O'Donnell, 'The State, Democratization, and Some Conceptual Problems' in William C. Smith, Carlos H. Acuña and Eduardo A. Gamarra (eds), Latin American Political Economy in the Age of Neoliberal Reform. Theoretical and Comparative Perspectives for the 1990s (New Brunswick: Transaction, 1994), pp. 157-179; 162.

${ }^{92}$ See Muna Ndulo, 'The Democratization Process and Structural Adjustment in Africa.' Indiana Journal of Global Legal Studies 10(1) (2003): 315-368; 320-1.

${ }^{93}$ Generally see, Englebert, State Legitimacy, p. 137; Richard Sandbrook, 'The State and Economic Stagnation in Tropical Africa.' World Development 14(3): 319-332; 324.

${ }^{94}$ See Donald Rothchild, 'Ethnic Bargaining and State Breakdown in Africa.' Nationalism and Ethnic Politics 1(1) (1995): 54-72; 58.
} 
Notably, many African states have cemented their acceptance in society via the patrimonial allocation of resources to different sub-national constituencies, and even by negotiating with distinct sectors of the population as co-sovereigns. ${ }^{95}$ Alternatively, many African states have preserved their authority by allocating privileges to one particular group, so anchoring state authority in specific, more exclusive sub-national affiliations. ${ }^{96}$ In both scenarios, weak peripheral inclusion means that the state is obliged to purchase support by distributing power and privilege amongst local dignitaries, so that the basic foundations of the state rest on a highly politicized, but ultimately also illusory and fragile, balance between public officials and privately motivated groups. ${ }^{97}$ In many cases, the persistence of local power simply means that centres of private or customary authority sit alongside more stable public institutions, so that effective authority is split between formal and informal actors. ${ }^{98}$ In many African societies, in short, peripheral and ethnic centrifugality has deeply eroded the basic hardness and relative autonomy (i.e. the distinctive public authority or sovereignty) of political institutions. This usually results in over-politicization of ethnic interests and in pathological forms of structural privatism in the political system, both of which phenomena closely mirror the results of inclusionary crises induced by the political incubation of class conflict.

In these settings, however, the recent rise of international human rights law has again formed an instrument through which national political systems have been able to compensate for their inclusionary problems. The rise of international human rights law has promoted alternative modes of legal inclusion in national societies marked by a strong centre/periphery split, and it has made it easier for the political system in such societies to

\footnotetext{
${ }^{95}$ See Rhoda E. Howard, 'Legitimacy and Class Rule in Commonwealth Africa: Constitutionalism and the Rule of Law.' Third World Quarterly 7(2) (1985): 323-347; 331.

${ }^{96}$ One obvious case of this is Kenya under Kenyatta. See David Withroup, 'The Construction and Destruction of the Kenyatta State' in Michael G. Schatzberg (ed), The Political Economy of Kenya (New York: Praeger, 1987), pp. 33-74; 39. The sub-national basis of state support then shifted under Moi (ibid p. 67).

${ }^{97}$ Rhoda E. Howard, 'Legitimacy and Class Rule in Commonwealth Africa: Constitutionalism and the Rule of Law.' Third World Quarterly 7(2) (1985): 323-347; 331; Bruce J. Berman, 'Ethnicity, Patronage and the African State: The Politics of Uncivil Nationalism.' African Affairs 97 (1998): 305-341; 334.

${ }^{98}$ See Donald I. Ray, 'Divided Sovereignty in Ghana.' Journal of Legal Pluralism and Unofficial Law 37/38 (1996): 181$202 ; 191$.
} 
perform reasonably consistent legal functions, without destabilizing exposure to regional and ethnic centrifugality.

In the first instance, manifestly, the rise of international law after 1945 did little to induce refined inclusivity in societies marked by diffuse regionalism or complex ethnic structures, and classical international law was scarcely adjusted to acentric demands for inner-societal inclusion. It is widely acknowledged that international law originally promoted very homogenous models of statehood, based in positivist accounts of sovereign state power as an indivisible centre of legal order. ${ }^{99}$ More concretely, further, the positivist bias in classical international law was directly refracted in political practice after 1945 , and positivistic concepts of statehood assumed particular importance in societies affected by deep problems of multi-centric inclusivity. During the Cold War, for example, the governments of China and Russia expressed strong reservations about international law and the normative standing of human rights conventions, and they endorsed positivist constructions of sovereignty in order to explain their position in the global legal order, and to proclaim their domination of their loosely connected domestic territories and constituencies. ${ }^{100}$ During the years of African decolonization, similarly, the polities of newly independent societies were marked, almost without exception, by a one-sided sovereignty-based conception of human rights. ${ }^{101}$ In this model, human rights were defined almost exclusively as rights of national self-determination. As such, rights were used to promote unitary nation building within simply defined national societies, and to defend the sovereignty of newly formed, structurally exposed, states against foreign

\footnotetext{
${ }^{99}$ Antony Anghie, Imperialism, Sovereignty and the Making of International Law (Cambridge: Cambridge University Press, 2004), pp. 8, 32; Oboira Chinedu Okafor, 'After Martyrdom: International Law, Sub-State Groups, and the Construction of Legitimate Statehood in Africa.' Harvard International Law Journal 41(2) (2000): 503-528; 504, 526; Paul Keal, European Conquest and the Rights of Indigenous Peoples. The Moral Backwardness of International Society (Cambridge: Cambridge University Press, 2003), p. 84

${ }^{100}$ Notably, see Suzanne Ogden, 'Sovereignty and International Law: The Perspective of the People's Republic of China.' New York University Journal of International Law and Politics 7 (1974): 1-32: 12, 19; Frédéric Krumbein, 'Die Menschenrechtslage in China nach 30 Jahren.' Zeitschrift für Außen- und Sicherheitspolitik 3 (2010): 309-335; 311; Björn Ahl, Die Anwendung völkerrechtlicher Verträge in China, Beiträge zum ausländischen öffentlichen Recht und Völkerrecht, 207 (Berlin: Springer, 2009), pp. 29, 44-5, 64.

${ }^{101}$ For comment see Evarist Baimu and Kathryn Sturman, 'Amendment to the African Union's Rights to Intervene.' African Security Review 12(2) (2003): 37-45; 39; Vincent O. Nmehielle, 'The African Union and African Renaissance: A New Era for Human Rights Protection in Africa?' Singapore Journal of International and Comparative Law 7 (2003): 412-446; 413, 420; Frans Viljoen, International Human Rights Law in Africa (Oxford: Oxford University Press, 2007), p. 163
} 
intervention, usually by former metropolitan powers. Tellingly, during the era of decolonization, the UN specifically formulated post-colonial rights as rights to selflegislation, not by single persons, but by nations, separated by clear saltwater from former imperial states. ${ }^{102}$ Still more tellingly, the 1963 Charter of the Organization of African Unity placed high emphasis on the inviolability of the national jurisdiction of sovereign states, and it rejected intervention by external powers in national domestic politics - even in cases of mass-atrocity. ${ }^{103}$

Nonetheless, in recent years, international law has clearly transferred its primary emphasis from rights of nations to rights of persons, and, in face of growing presumptions in favour of human rights, international law can no longer be viewed as a late outgrowth of nineteenth-century positivism. Now, albeit incompletely, international law has become sensitive to the fact that many national societies contain pluralistic social environments. In consequence, international law now generates plural rights, and it is able to incorporate multiple, often interwoven, legal personalities, which do not easily accord with classical mono-centric patterns of statehood and nationhood. Indeed, the application of international law increasingly acts as the precondition both for legal inclusion and for political system building in societies containing multiple communities and plural claims to legal recognition. Paradoxically, in fact, international human rights norms have assumed greatest inclusionary relevance for national political systems which were originally most intent on proclaiming simple national sovereignty as the sole foundation of legal order: that is, for political systems that are expected to govern diffusely connected or concentric societies. In many instances, the traditional weakness in inclusionary or systemic structure characterizing such polities has been - at least in part - allayed by the implementation of international rights norms, and by the inclusionary flexibility made possible by such norms. Indeed, paradoxically, the inclusionary structure or the effective sovereignty of such states has derived far more substantial reinforcement from singular/pluralistic models of human

\footnotetext{
102 Note especially UN resolution 1514 (1960).

${ }^{103}$ See B. Obinna Okere, 'The Protection of Human Rights in Africa and the African Charter on Human and Peoples' Rights: A Comparative Analysis with the European and American Systems.' Human Rights Quarterly 6(2) (1984): 141$159 ; 158$.
} 
rights law than it was ever able to obtain from the more strictly positivist ideals underpinning classical international law.

To illustrate this, on one hand, the penetration of international human rights norms into domestic legal systems has brought clear political/structural advantages for societies whose political systems have traditionally been marked by reliance on informally constituted power in remote localities. An important early precedent for this was the USA itself, in the decades following 1945. In the USA at this time, the (partial) assimilation of international human rights law was instrumental in the establishment, to a large degree by judicial actors, of a reasonably uniform and consistently inclusive legal/political order. At this time, national government and the national legal system were finally consolidated as general systems of inclusion, able to reach into all parts of the nation, to bring all citizens of whatever ethnic background - under federal jurisdiction, and to weaken the standing of local power monopolies. ${ }^{104}$ More recently, however, this inclusionary role of human rights has been especially pronounced in China and Russia. In recent years, both these societies have witnessed a gradual (although clearly only patchy) acceptance of expectations regarding national compliance with international rights norms, and, in both cases, this has served - however imperfectly - to extend the inclusionary reach of the political system into society. ${ }^{105}$ In particular, this is due to the fact that the growing intersection between domestic law and international law has established stricter principles of legitimacy for law, and it has elevated standards of procedural control in judicial functions. As a result, the increasing use of international law has served more formally to segregate the functions of the political system from local or private authority, reducing the importance of personal standing, and rendering private elites less valuable as points of political support for the state. ${ }^{106}$ In each respect, the internalization of international human rights law has

\footnotetext{
${ }^{104}$ See note 106 below.

${ }^{105}$ For background, see John P. Willerton, Patronage and Politics in the USSR (Cambridge: Cambridge University Press, 1992), p. 227; Gerald M. Easter, Reconstructing the State. Personal Networks and Elite Identity in Soviet Russia (Cambridge: Cambridge University Press, 2000), pp. 67, 89; Neil Munro, 'Connections, Paperwork or Passivity: Strategies of Popular Engagement with the Chinese Bureaucracy.' The China Journal 68 (2012): 147-175; 171.

${ }^{106}$ Consider the rise in influence of international treaties as background to the legal success of the Civil Rights movement and the weakening of the power of the states, which this implied. See for commentary Lucas A. Power, Jr, The Warren Court and American Politics (Cambridge, MA: Harvard University Press, 2000), p. 112; Rawn James Jr.,
} 
facilitated the relatively simple and depersonalized reproduction of law and political authority across society as a whole.

On the other hand, the rise of international human rights law has brought distinctive benefits to the inclusionary structure of different post-colonial societies. At one level, this process is rather similar to that in Russia and China. In many post-colonial societies, the interaction between national law and international human rights law has heightened the (historically only notional) integrity of the judicial branch, and it has made it possible to elevate judicial power above personal/patrimonial influence, thus simplifying the extension and reproduction of law across society. ${ }^{107}$ In many such cases, however, the assimilation of human rights norms from the international legal domain has brought additional inclusivity to national legal/political systems because it has enshrined principles for promoting non-conflictual inclusion of minority or indigenous populations, existing in parallel to historically dominant national groups. In this respect, the assimilation of international human rights law helps to secure inclusionary procedures through which multi-centric societies can soften and de-politicize historically endemic conflicts between dominant population groups and indigenous communities, and so avoid exposure to recurrently unbearable antagonism between central and peripheral groups.

The ability of international law to create normative structures adjusted to postcolonial societies containing indigenous communities is visible, first, in international normative instruments and in the jurisprudence of international courts. Most significant in this regard is the fact that international human rights law concerning indigenous communities has moved irrevocably away from the nationally integrationist, essentially sovereigntist, underpinnings of post-1945 inter-state relations. ${ }^{108}$ Shaped initially by

Root and Branch. Charles Hamilton Houston, Thurgood Marshall, and the Struggle to End Segregation (New York: Bloomsbury Press, 2010), p. 189.

${ }^{107}$ It is commonly argued that the judiciary was 'irrelevant' or a mere 'handmaiden' to executive authority in prereformist Africa. See Victor Azarya and Naomi Chazan, 'Disengagement from the State in Africa: Reflections on the Experience of Ghana and Guinea.' Comparative Studies in Society and History 29(1) (1987): 106-131; 124; Charles Manga Fombad, 'A Preliminary Assessment of the Prospects for Judicial Independence in Post-1990 African Constitutions.' Public Law 2 (2002): 233-257; 234. For similar tendencies in Latin America see Pilar Domingo, 'Judicial Independence and Judicial Reform in Latin America,' in Andreas Schedler, Larry Diamond and Marc F. Plattner (eds), The Self-Restraining State. Power and Accountability in New Democracies (Boulder: Rienner, 1999), pp. 151-176; 156.

${ }^{108}$ See Okafor, Re-Defining Legitimate Statehood, p. 159. 
guidelines of the ILO (especially Convention nr. 169 (1989)), contemporary international law gives express recognition to ethnic group rights, and even to collective communal rights, and it establishes rights that give standing under law to different populations within varied, multi-centric national societies. In the UN Declaration on the Rights of Indigenous Peoples (2007), notably, the classical right to self-determination, which had shaped the typically nationalist course of post-colonial state building, was subtly modified, and it began to cover constitutional claims to varying degrees of autonomy, and to acknowledge multiple legal personalities, for prior and indigenous communities within national states. ${ }^{109}$ In parallel to this, regional human rights instruments have also been interpreted to provide extensive protection for the particularist rights claims of non-dominant populations. For example, in 1997, the Inter-America Commission on Human Rights approved a draft of a Proposed American Declaration on the Rights of Indigenous Peoples. In 2016, the final version of this document was adopted by the General Assembly of the Organization of American States. This Declaration specifically protects the rights of indigenous peoples in the region. ${ }^{110}$ In addition, the IACtHR has used the provisions for the right to life in the ACHR to develop the principle that all signatories must guarantee to persons and to collectives the right to 'vida digna', which is often construed to imply rights to the protection of land and preservation of culture for indigenous communities. ${ }^{111}$ To an increasing degree, therefore, international law is able to reflect the fact that some societies contain pluralistic, perhaps hybrid, modes of affiliation, and it enables societies to respond to claims for legal inclusion that are not reducible to positivistic categories of legal recognition. This has particular relevance for societies, in which the imposition of central state power was bound up with the administrative legacy of colonialism, and in which prior

\footnotetext{
${ }^{109}$ See Stefania Errico, 'The Draft UN Declaration on the Rights of Indigenous Peoples: An Overview.' Human Rights Law Review 7(4) (2007): 741-755;

${ }^{110}$ See more details of the adoption of the American Declaration on the Rights of Indigenous Peoples in: http://www.oas.org/en/media_center/press_release.asp?sCodigo=E-075/16.

${ }^{111}$ Jo M. Pasqualucci, 'The Right to a Dignified Life (Vida Digna): The Integration of Economic and Social Rights with Civil and Political Rights in the Inter-American Human Rights System.' Hastings International and Comparative Law Review 31(1) (2008): 1-32; 2-3, 14-5. The Inter-American Court first upheld claims for indigenous collective land rights in Awas Tingni (2001), arising in Nicaragua. But this was more strictly formalized in the Yakye Axa (2005) case in Paraguay. See Jo M. Pasqualucci, 'The Evolution of International Indigenous Rights in the Inter-American Human Rights System.' Human Rights Law Review 6(2) (2006): 281-322; 299, 311.
} 
populations have rejected the blank imposition of uniform legal order. In such cases, international human rights law has been able to create foundations for a multi-inclusionary legal system, in which different groups can obtain legal inclusion outside the strict confines of national institutions.

However, the impact of such tendencies in international is most potent, not in supranational instruments or jurisdictions, but in the jurisprudence of national courts located in societies with pluralistic populations, especially in Southern Africa and Latin America. ${ }^{112}$ In South Africa itself, for example, the strong presumption in favour of international law contained in the post-apartheid constitutional texts led to the granting of wide recognition for customary (i.e. tribal) law and for rights defined under customary law. ${ }^{113}$ This in mirrored in other African societies which have undergone constitutional transition in recent decades. For example, the 1992 Ghanaian constitution clearly establishes a legal order, which is defined by uniformity in the application of highest constitutional principles. However, this constitution also recognizes the customary law of 'particular communities' (Art 11(3)), and it guarantees the preservation of some traditional institutions. Similarly, in Latin America, Colombia, Ecuador, and Bolivia have led the way in devising constitutions that promote multi-focal patterns of political affiliation. In some of these countries, constituent assemblies drafting new constitutions have included representatives of prior populations, and under these constitutions municipal high courts have often insisted on strict entrenchment of constitutional rights for indigenous

\footnotetext{
112 Jacques Mariel Nzouankeu, 'Decentralization and Democracy in Africa.' International Review of Administrative Sciences 60 (1994): 213-227; 224-5; Frans Viljoen, International Human Rights Law in Africa (Oxford: Oxford University Press, 2007), p. 242; Asbjørn Eide, 'Rights of Indigenous Peoples - Achievements in International Law during the Last Quarter of a Century.' Netherlands Yearbook of International Law 37 (2006): 155-212; 169; James S. Anaya, 'Indigenous Rights Norms in Contemporary International Law.' Arizona Journal of International and Comparative Law 8(2) (1991): 1-39. Donna Lee Van Cott, 'A Political Analysis of Legal Pluralism in Bolivia and Colombia.' Journal of Latin American Studies 32(1) (2000): 207-234; 210, 214; Federico Lenzerini, 'Sovereignty Revisited: International Law and Parallel Sovereignty of Indigenous Peoples.' Texas International Law Journal 42 (2007): 155-189; 167. On the specific link between the promotion of tolerance for cultural differences and the openness to international law in many Latin American societies see Rodrigo Uprimny, 'The Recent Transformation of Constitutional Law in Latin America: Trends and Challenges.' Texas Law Review 89 (2011); 1587-16-9; 1593.

${ }^{113}$ Chuma Himonga and Craig Bosch, 'The Application of African Customary Law under the Constitution of South Africa: Problems Solved of Just Beginning.' The South African Law Journal 117 (2000): 306-341; 312.
} 
communities. ${ }^{114}$ Notably, the Colombian Constitutional Court has adopted a policy of maximization in addressing indigenous rights. It has argued that 'a high degree of autonomy' is a precondition for the survival of indigenous communities, and that 'maximization of the autonomy of indigenous communities' and 'minimization of the restrictions' imposed on this autonomy should be viewed as a rule in relevant jurisprudence. $^{115}$

In discussing this, it is of course vital to note that constitution writing in these societies has been partly shaped by overt hostility to international law, at least international economic law. Many new Latin American constitutions have attempted to locate sovereignty in the live exercise of constituent people by the national people, and they have selectively restricted the force both of international norms and judicial tribunals. The 2009 Bolivian Constitution, notably, declares that the constitution itself is the highest source of norms in the state, and it subordinates all other law to the will of the constituent people, sharply prohibiting the use of some international law, especially in the economic domain, to override domestic law (Art 366). In Art 196, it declares that the Constitutional Tribunal is bound to the will of the national constituent power, and the national constituent power, rather than any abstracted norms, is to be recognized by the courts as the most authoritative criterion for interpretation of laws.

Nonetheless, international norms have clearly impacted on constitution writing in these societies, and general international human rights treaties remain pervasive in domestic public law. ${ }^{116}$ For instance, Art 256 of the Bolivian Constitution places international human rights treaties above domestic constitutional law. Moreover, with some qualifications, Art 410 establishes the doctrine of the block of constitutionality,

\footnotetext{
${ }^{114}$ The Constitution of Bolivia (Arts 1-2) notably guarantees defines the state as a pluri-national state and guarantees rights indigenous self-government and autonomy. For comment see Pascal Lupien, 'The Incorporation of Indigenous Concepts of Plurinationality into the New Constitutions of Ecuador and Bolivia.' Democratization 18(3) (2011): 774796. The advent of constitutional commitment to plurinationalism was preceded by laws providing for decentralization of government.

${ }^{115} \mathrm{~T}-349 / 96$.

${ }^{116}$ See Carlos Alberto Goitia Cabballero, 'La supremacía constitucional en Bolivia.' Foro. Revista de Derecho 12 (2009): 181-220; 200
} 
allowing the Constitutional Court to incorporate human rights law directly in its rulings. ${ }^{117}$ In fact, in Bolivia, the impact of international law is especially evident in questions concerning indigenous peoples and particularist rights claims. International law played an important role in the rise of pluri-national constitutionalism. Significantly, Bolivia was quick to accede to Convention 169 of the ILO. ${ }^{118}$ In fact, the Convention was drafted by the Bolivian Ambassador to the ILO, and Bolivia has been especially rigorous in prosecuting cases of non-observance. ${ }^{119}$ Analogously, the Colombian Constitutional Court, acting in strict fidelity to international law, has been singularly active in implementing internationally constructed rights for prior populations. ${ }^{120}$ In these cases, thus, the formation of multi-inclusionary political structures results directly from innovations in international law.

Of particular note in this regard is the fact that the international promotion of divergent group rights has often been reflected in a decentralization of national state structures. To this degree, it has led to the construction of state institutions that are less likely to encounter obdurate obstruction caused by the conflicts inherent in pluralistic social environments. As discussed, in both Latin America and Africa, the processes of constitutional reform conducted in the 1990s were intended to provide alternatives to the bloated states that had grown out of decolonization. They sought to achieve this, in part, by introducing laws for (in however imperfect fashion) empowering local authorities and municipalities, ${ }^{121}$ which in some cases were controlled by indigenous groups. One African example of recent decentralization is the provision for administrative decentralization (Art 241(c)) in the Ghanaian Constitution of 1992. The South African constitution grants distinct rights for local and ethnic communities, especially in Art 212(1). A notable South American

\footnotetext{
${ }^{117}$ See also Constitutional Court ruling 0085/2012.

${ }^{118}$ Alison Brysk and Carol Wise, 'Liberalization and Ethnic Conflict in Latin America.' Studies in Comparative International Development 32(2) (1997): 76-104; 90, 96; Nancy Grey Postero, Now We Are Citizens. Indigenous Politics in Postmulticultural Bolivia (Stanford, CA.: Stanford University Press, 2007), p. 51.

${ }^{119}$ S. James Anaya, 'International Human Rights and Indigenous Peoples: The Move Toward the Multicultural State.' Arizona Journal of International and Comparative Law 21(1) (2004): 13-61; 24, 54

${ }^{120}$ See Donna Lee van Cott, 'Latin America: Constitutional Reform and Ethnic Right.' Parliamentary Affairs 41-54; 45.

${ }^{121}$ For more sceptical comment, noting the continued absence of public authority at local level, see Thomas Bierschenk and Jean-Pierre Olivier de Sardan, 'Powers in the Village: Rural Benin between Democratization and Decentralisation.' Africa 73(2) (2003): 145-173; 146, 154.
} 
example of constitutional decentralization this is the Bolivian Popular Participation Law (1994), which was later assimilated in Arts 200-206 of the reformed Bolivian Constitution of 1994, and reinforced in the Administrative Decentralization Law of $1995 .{ }^{122}$

Significantly, the decentralization of state functions and the rise of multiinclusionary statehood in such societies were induced - in part - by the earlier liberalizing policies of the IMF in the 1980s. One reason why claims for regional and ethnic rights and for decentralized representation became salient through the 1990s is that liberal reform policies had reduced the reach and density of the state, and they had often diminished the political relevance and integrative force of economic organizations. ${ }^{123}$ This meant that groups which had formerly been connected to the state through corporate or patrimonial lines of inclusion experienced a partial disengagement from the state, and they were required to re-articulate their relation to the state and to construct a medium of inclusion not based in material incorporation or patronage. ${ }^{124}$ In some societies with large prior populations, indigenous groups whose link to the state had been constructed through strategies of peasant corporatism, in which allocation of privileges and goods to peasant communities was assigned nation-building functions. ${ }^{125}$ Decentralized pluralism, however, began to propose itself as an alternative system of inclusion to corporatism as the state's material hold on society was weakened through externally dictated reform. Tellingly, one commentator has observed how, in many societies, the stripping back of the corporate state in the 1980s created new opportunities for pluralist democracy and multiple forms of

\footnotetext{
${ }^{122}$ For comment on Bolivia see Kathleen O'Neill, Decentralizing the State. Elections, Parties, and Local Power in the Andes (Cambridge: Cambridge University Press, 2005), p. 63; Miguel Centellas, 'Bolivia's New Multicultural Constitution: The 2009 Constitution in Historical and Comparative Perspective' in Todd A. Eisenstadt, Michael S. Danielson, Moisés Jaime Bailón Corres and Carlos Sorroza Polo (eds), Latin America's Multicultural Movements. The Struggle Between Communitarianism, Autonomy, and Human Rights (Oxford: Oxford University Press, 2003), pp. 88110; 94

${ }^{123}$ Note in particular Art 1 of the Bolivian Constitution of 2009.

${ }^{124}$ See Deborah J. Yashar, 'Contesting Citizenship: Indigenous Movements and Democracy in Latin America.' Comparative Politics 31(1) (1998): 23-42; 34-35; Salvador Schavelzon, El nacimiento del estado plurinacional de Bolivia. Etnografía de una Asemblea Constituyente (La Paz: CLACSO- PLURAL-IWGIA-CEJIS2012), pp. 11, 92

${ }^{125}$ Antonio García, 'Los sindicatos en el esquema de revolución nacional: El sindicalismo en la experiencia boliviana de nacionalización y desarrolo.' El triestre económico 33(132((4)): 597-629; 598, 606.
} 
citizenship, ${ }^{126}$ and states began to utilize plural rights, instead of material incorporation, as channels of legal inclusion. As even the harshest critics of 1980s neoliberalism have noted, this led in some societies to a 'redefinition and remodelling' of the state on a multi-centric, multi-spatial design, ${ }^{127}$ in which less socially convergent patterns of inclusion assumed significance, and in which the burden of legal integration now no longer falls exclusively on a narrow set of centralized institutions.

On this basis, the international rise of human rights law has had the effect that, at one level, it constructs groundrules to define essential and relatively uniform principles of normative order within national states and their legal systems. Yet, as Talcott Parsons first observed in his deep moral reflections on the inclusionary role of rights in his own national society, ${ }^{128}$ international human rights law also permits a high degree of variance or normative multiplicity in national legal systems, and it enables the coexistence of diverse legal structures and diverse patterns of cultural affiliation and behavioural emphasis in different societies. ${ }^{129}$ In certain respects, the absorption of international human rights law into national societies institutes a transnational legal system within domestic jurisdictions, by means of which variable, multi-dimensional media of legal inclusion can be activated. That is to say, on one hand, that, to an increasing degree, human rights norms, initially derived from international conventions, establish basic legal principles to underpin a simple system of legal inclusion in national societies, so that single persons, qua formal rights holders, can be included in certain general dimensions of their lives: rights define a thin set of overarching norms to regulate legal and political exchanges, for which only few social interactions have very pressing relevance. On the other hand, however, human

\footnotetext{
${ }^{126}$ Ben Gustafson, 'The Paradoxes of Liberal Indigenism: Indigenous Movements, State Processes, and Intercultural Reform' in D. Maybury-Lewis (ed), The Politics of Ethnicity in Latin American States (Cambridge: Harvard University Press, 2002), pp. 267-306; 280.

${ }^{127}$ Hibou, 'From Privatising the Economy to Privatising the State', p. 24.

${ }^{128}$ Talcott Parsons, 'Full Citizenship for the Negro American? A Sociological Problem.' Daedalus 94(4) (1965): 10041054.

${ }^{129}$ For example, the Colombian Constitutional Court has ascribed great importance to indigenous rights. Yet, it has also remained insistent that customary laws must comply with residual rights standards. See Donna Lee van Cott, 'Latin America: Constitutional Reform and Ethnic Right.' Parliamentary Affairs 53(1) (2000): 41-54; 45. Likewise, the South African Constitutional Court has refused to vindicate cultural rights in contravention of the Bill of rights. See Himonga and Bosch, 'The Application of African Customary Law', pp. 311-12.
} 
rights abstract the foundations for a legal system, in which societies are able, where there is no express or essential conflict between general and group-specific rights, to permit, and even to promote, parallel or pluralistically coexistent modes of affiliation, sovereignty, legal custom, and political participation, often overlayering basic singular rights with thicker group rights. ${ }^{130}$ Human rights thus construct a divisible, multi-centric legal order, which is - to some degree, at least - more adequately adapted to societies marked by an uneasy fit between statehood, local legal tradition, and political loyalty.

Above all, the transnational diction of rights means that populations in national societies can assume multiple legal personalities, partly under national and international law, and they can seek inclusion in many legal dimensions at the same time, often operating between the strictly national and the strictly international tiers of global legal order. ${ }^{131}$ This means that many of the social conflicts traditionally incorporated by the state can be displaced from central institutions, and it allows society as a whole to deemphasize and to de-politicize endemic conflicts between political centre and social periphery. States are thus able to build normative order in society without forcing society into convergence around simplified, uniform, or unsustainably politicized acts of agreement or patterns of affiliation, the weight of direct inclusionary burdens placed on single centralized state institutions is greatly reduced. ${ }^{132}$ of course, it is widely observed that peripheral or minority communities attach great political intensity to the conflict for rights - especially where these are linked to sub-national identities. ${ }^{133}$ Clearly, it is emphatically the case, in such circumstances, that claims to group rights often result in the sporadically heightened politicization of certain social contests and affiliations. However, such partial politicization occurs against a background in which rights have made the total

\footnotetext{
${ }^{130}$ See Lupien, Incorporation of Indigenous Concepts of Plurinationality', p. 780; Siegfried Wiessner, 'Indigenous Sovereignty: A Reassessment in Light of the UN Declaration on the Rights of Indigenous Peoples.' Vanderbilt Journal of Transnational Law 41 (2008): 1141-1176; 167

${ }^{131}$ By this I mean that groups raising claims to indigenous rights at times elevate themselves into a zone where they assume justification under international law, and so, to some extent, suspend some of the force of, and limit their obligation to, municipal law. However, this does not need to result in a condition approaching secession. See Lenzerini, 'Sovereignty Revisited', p. 167.

${ }^{132}$ On this legal point see Russel Lawrence Barsh, 'Indigenous Peoples in the 1990s: From Object to Subject of International Law?’ Harvard Human Rights Journal 7 (1994): 33-86; 66.

${ }^{133}$ See Yashar, 'Contesting Citizenship', p. 39
} 
politicization of society - its emphatic convergence around single, simple, indivisible processes of inclusion - somewhat improbable, and in which frontal conflicts between centrally and peripherally located groups can be conduced at a reduced level of controversy.

In this respect, we can see an analogy between the status of human rights vis-à-vis the problems of systemic inclusion induced by class conflict and the status of rights vis-àvis the systemic inclusion of centre/periphery divisions. Human rights provide a vocabulary in which the national state can sidestep the second great challenge to its formation as an autonomous and public normative system - the conflict between centre and periphery or peripheries. The momentum for systemic differentiation engendered by human rights norms underlies the effective construction of the political system as a normative order that is not endlessly unsettled, excessively politicized, and typically re-privatized, as a result of regional centrifugal impulses. Indeed, in parts of Southern Africa and Latin America, where statehood has traditionally been challenged by extreme regional centrifugality and resultant loss of public distinction, the consolidation of state institutions at a local level, and the overlapping of state legality, international legality, and customary legality, has helped to cement public authority against inner corrosion. The rights-mediated interlocking of different legal orders widely creates a new basis for a discernibly public system of inclusion. ${ }^{134}$

\subsection{International human rights and the production of law}

The structure-building role of international human rights law is also visible in a third domain of inclusion, in the national states have been beset by deeply unsettling inclusionary pressures. In this case, pressures result from the fact that, during the course of its formation and its social and geographical extension, the modern national state was expected to generate a constantly increasing volume of law in order to address the inclusionary demands presented to it. In many examples, state institutions have been

\footnotetext{
${ }^{134}$ For examples see Green, 'Ghana: Structural Adjustment and State (Re)Formation', p. 189; John-Andrew McNeish, 'Constitutionalism in an Insurgent State: Rethinking Legal Empowerment of the Poor in a Divided Bolivia' in Dan Banik (ed), Rights and Legal Empowerment in Eradicating Poverty (Farnham: Ashgate, 2008), pp. 69-96; 79, 89.
} 
simply overburdened and brought to crisis by the rising material requirement for law in modern society, and few national states have been able to develop instruments for the creation of an adequate quantity of legal statutes for their societies. This third inclusionary crisis of the modern state is thus a crisis of legal inclusion.

Most typically, the pressure for states to increase and intensify the production of law resulted, first, in the expansion and intensification of parliamentary activity; as states first assumed broadly inclusive law-making functions, parliaments and parliamentary committees briefly became the central components of the political system. ${ }^{135}$ Almost invariably, this pressure resulted, second, in the development of corporatist models of socio-political inclusion, through which consensual fora for professional and local interest representation were placed in the state periphery, alongside the organs of parliament. ${ }^{136}$ The institution of corporatist bodies was intended both to increase the state's capacity for producing economic legislation, and to extend the penetration of law (both in origin and application) more deeply into society. ${ }^{137}$ In most instances, however, emerging modern states proved quite incapable of generating the required volume of legislation for society, and usually both their parliamentary and their corporatist mechanisms for creating and authorizing law misfired - often disastrously. At a very basic level, most national parliaments were rapidly over-taxed by their growing legislative functions. As a result, parliamentary bodies were soon displaced by executives as centres of the legislative system: the assumption that legislation is conducted by elected legislators is, even in the

\footnotetext{
${ }^{135}$ See for one example Martin Burch and Ian Holliday, The British Cabinet System (London: Harvester Wheatsheaf, 1996), p. 12

${ }^{136}$ Some early mass democracies, for example Italy and Germany, experimented with the creation of corporateeconomic parliaments, standing beside the generally elected parliaments. Even where this was not the case, for example in the UK, early mass-democratic politics were shaped by a strong corporate bias. See the argument in Keith Middlemas, Politics in Industrial Society: The Experience of the British System since 1911 (London: André Deutsch, 1979).

${ }^{137}$ As discussed, the development of corporatism was widespread in nations that followed a developmentalist path into capitalist modernity. However, the emergence of committee structures as antennae reaching into society was also a feature of polities without an especially strong corporate dimension. On the UK for example see K.C. Wheare, Government by Committee. An Essay on the British Constitution (Oxford: Clarendon, 1955), pp. 142-3. The switch from parliamentary to corporate legislation in more strongly corporate polities usually occurred at the same time as the transition to a mass franchise. See for example Maria Elvira Lanciotti, La riforma impossibile. Idee, discussioni e progetti sulla modifica del senato reghio e vitalizio (1848-1922) (Bologna: Gedit edizioni, 2004), pp. 301-6. For general analysis see Charles S. Maier, Recasting Bourgeois Europe: Stabilization in France, Germany and Italy in the Decade after World War I (Princeton: Princeton University Press, 1975).
} 
most consolidated democracies, barely more than a fiction. ${ }^{138}$ Equally importantly, the corporatist/consensual devices used for engendering economic law also usually collapsed before they were fully established, and, in most states, corporatist bodies were rapidly transformed into organs of executive action and coercion. ${ }^{139}$ In the development of the mass-democratic national state, therefore, political institutions were widely brought to crisis by the accelerated growth in society's consumption of law. The need for increased law production typically led to an over-politicization of the political system (unmanageable demands for legislation, uncontrollable incorporation of rival organizations). This, in turn, usually led to a rapid transfer of power to executive bodies, which were able to bypass the cycles of politicization attached to parliamentary and corporatist institutions. In most mass-democratic polities, consequently, executive organs became dominant bodies within the state, and, in most cases, executive organs, detached from their co-ordinate branches of government, became closely linked to strong private organizations, whose interests could easily be enacted through the prerogative force of executive acts. ${ }^{140}$ In many settings, accordingly, the ability of the state to penetrate into society has been diminished by the fact that it has lacked resources for evenly reliable legislation, and it has suffered from chronic under-production of law in quite general terms. As in other cases of inclusionary pressure, this has tended to stimulate privatism and structural crisis in the political system.

The assimilation of international human rights norms in domestic legal systems, however, has altered the capacity of national states for the production of law in a number

\footnotetext{
${ }^{138}$ See Edward C. Page, Governing by Numbers. Delegated Legislation and Everyday Policy-Making (Oxford: Hart, 2001), p. 157. For general near-commentary on this process see James Bryce, Modern Democracies, 2 vols. (London: Macmillan, 1923), 2: 374; Charles Grove Haines, 'Ministerial Responsibility Versus the Separation of Powers.' The American Political Science Review 16(2) (1922): 194-210; 199, 203.

${ }^{139}$ Tellingly, the leading theorist of corporatism in Italy, Alfredo Rocco, supported his vision of corporate order by arguing that in modern societies the government (executive) has the authority to exercise executive powers of legislation usually ascribed to parliament. He construed corporatism as a legal order culminating in an all-powerful executive, authorized to make 'laws by decree (decreti-leggi)': Alfredo Rocco, Discorsi parlamentari (Bologna: Mulino, 2005), pp. 222, 218.

${ }^{140}$ This was also the case in polities, such as the UK, which survived the transition to mass-democracy without deep structural crisis. See Terence Daintith and Alan Page, The Executive in the Constitution. Structure, Autonomy and Internal Control (Cambridge: Cambridge University Press, 1999), p. 240; Henry Parris, Constitutional Bureaucracy. The Development of British Control of British Central Administration since the eighteenth Century (London: Allen and Unwin, 1969), p. 184; Philip Allott, 'The Courts and Parliament: Who Whom?' The Cambridge Law Journal 38(1) (1979): 79-117; 115; Craig, Administrative Law, p. 94.
} 
of different ways. In most cases, national societies have been able substantially to increase their ability to generate law because of the growing intersection between national law and international law, especially international human rights law.

In the first instance, we can observe this increase in law-making capacity through rights in the simple legislative functions of national states. Through their growing conjunction with global human rights law, most national states have become much more effective, in general terms, in the consistent production and authorization of legislation. In particular, this results from the fact that in national societies in which international law plays a significant role, courts and other judicial bodies are able to supplement the legislative functions of parliaments. This allows societies to produce legislation without imputing sole law-making responsibility to single institutions, and it normally extends the general law-making capabilities of a given political system, especially in settings where legislative institutions are habitually overburdened by inclusionary pressures.

This phenomenon originally became evident through the application of international human rights law in post-authoritarian societies following World War II. After 1945, the implementation of human rights norms in societies such as West Germany and Italy led to a marked simplification in procedures for the creation and application of law, and it served greatly to expedite the positive reproduction of law across society at large. ${ }^{141}$ Examples of this, further, can be found in traditionally less well-structured political systems, for example in post-colonial societies in West and Southern Africa, in which the production of law has also been simplified through the assimilation of international law. The classic example of this is South Africa itself, where from 1995 the Constitutional Court, whose jurisprudence was particularly indebted to international law, ${ }^{142}$ assumed entitlement to invalidate pre-existing laws, to spell out principles for new legislation, and in fact to create law. ${ }^{143}$ In so doing, the court strengthened the law-making process against

\footnotetext{
${ }^{141}$ See pp. XXX above.

${ }^{142}$ Jeremy Sarkin, 'The Effect of Constitutional Borrowing on the Drafting of South Africa's Bill of Rights and Interpretation of Human Rights Provisions,' Journal of Constitutional Law 1(2) (1998): 176-204; $181,183$.

${ }^{143}$ Notably, see the opinion of Froneman $\mathrm{J}$ in Matiso and Others $v$ Commanding Officer, Port Elizabeth Prison and Other that the new South African Constitution merely formulated values and principles in general terms, and that 'the courts bear the responsibility of giving specific content to those values and principles in any given situation. In so doing, judges will invariably "create law"” (1994(4) SA 592 (SE)).
} 
hostile factions outside the political system and created a simple matrix in which, even against an acutely divided societal background, legislation could be engendered, authorized, and circulated through society in relatively consensual fashion. As a result, the South African Constitutional Court came to be viewed as the primary bearer of 'sovereignty' for the South African polity. ${ }^{144}$

Although such cases of inclusionary structure building through rights are more typical of crisis-afflicted polities, however, analogous cases can be found in more traditionally stable political systems. This phenomenon is also evidenced, for example, in the recent constitutional transformation of the UK and France. In these polities, notably, the rising influence of the ECHR in domestic jurisprudence means that the passage of statutes is subject to rights-based screening by lawyers co-opted to oversee legislative conduct. In both polities, this has the consequence that law is now generated from within a relatively uniform normative system, so that the consistency and quality of laws can be more easily secured. ${ }^{145}$ More debatably, this has the additional consequence that responsibility for authorizing law is separated from the simple momentary will of legislative majorities, and laws are produced and legitimized by multiple actors, from within a simple normative scheme, so that no one institution has responsibility for responding to all societal demands for law. ${ }^{146}$ Here too, therefore, the expectation that laws will be proportionate to overarching rights norms creates a multi-centric, yet internally coherent, legislative system, in which law can be produced by many institutions,

\footnotetext{
${ }^{144}$ Note the role of proportionality review in this process. See Dickson, 'Protecting Human Rights through a Constitutional Court', p. 534. For an overview of constitutional absorption of international law see Richard Frimpong Oppong, 'Re-Imagining International Law: An Examination of Recent Trends in the Reception of International Law into National Legal Systems in Africa.' Fordham International Law Journal 30 (2006): 296-345.

${ }^{145}$ See Janet L. Hiebert. 'Parliamentary Bills of Rights: An Alternative Model?' The Modern Law Review 69(1) (2006): 728. In the UK, it is now accepted that a 'strict test of proportionality' can be applied to executive acts by the courts, and that this helps to create a unitary legal framework for legislation, even removing some norms from the vicissitudes of social controversy. For comments to this effect see A \& Others $v$. Secretary of State for the Home Department [2004] UKHL 56. Some commentators argue that review for proportionality is 'inescapably an exercise in applied lawmaking': Alec Stone Sweet and Jud Matthews, 'Proportionality and Global Constitutionalism.' Columbia Journal of Transnational Law 47 (2008): 73-165; 161. See also Francis G. Jacobs, 'Recent Developments in the Principle of Proportionality in European Community Law' in Evelyn Ellis (ed), The Principle of Proportionality in the Laws of Europe (Oxford: Hart, 1999), pp. 1-23.

${ }^{146}$ Key evidence of this is found in a 2003 ruling of the British House of Lords, where it was stated that international human rights (the ECHR) had unique position in UK law, acting as a catalyst for all acts of legislation, and so allowing courts to assume unprecedented authority in shaping legislative outputs. See Wilson v First County Trust (No 2) [2003] UKHL 40.
} 
at a relatively high level of inner abstraction. ${ }^{147}$ In all such settings, the fact that courts have increasingly come to act as ancillary legislators has allowed the political system internally to insulate itself against unsettling external contest, to simplify and internally to harden its procedures for generating law, yet also to divide law-making functions across a range of institutions. In all such cases, the rise of transjudicial human rights norms as the basis for legislation has meant that the political system can respond in relative autonomy to societal requirements for legislation, and it can confer legitimacy on legislation through reference to internally stored positive principles. In each respect, in many cases, rights enable political actors to react independently to increasing, and politically unsettling, needs for law, and so to expand society's capacity for law production quite globally.

This impact of international rights norms on societal capacity for creating law, however, is not restricted to the legislative activities of national political systems. It is still more apparent in their judicial dimensions. Indeed, owing to the rise of international human rights norms, judicial institutions have begun to play a more effective role in raising social access to the law, in circulating law through society, and thus in increasing the volume of law that society as a whole is able to produce and consume. Famous examples of this are the USA, and, to an increasing degree, the member states of the European Union, where, owing to the rise of a common rights consciousness, the volume of litigation channelled through courts, and the quantity of law transmitted across society, have increased discernibly. ${ }^{148}$ However, the growing powers of judicial bodies have obtained particular inclusionary importance in societies with historically precarious and weakly inclusive state structures. In such societies, the increasing assimilation of international human rights law in national law has greatly enhanced the integrity of national judicial procedures, and it has played a vital role in widening law's reach into society. In these societies, the inclusionary functions of judicial institutions have been intensified by the fact that the use of human rights norms to underpin judicial rulings has helped to separate

\footnotetext{
${ }^{147}$ See Paul Craig, 'Ultra Vires and the Foundations of Judicial Review.' Cambridge Law Journal 57(1) (1998): 63-90; 70.

${ }^{148}$ Comparing the EU and the USA in this regard see Robert A. Kagan, 'Should Europe Worry about Adversarial Legalism?' Oxford Journal of Legal Studies 17(2) (1997): 165-1833; Daniel R. Kelemen, 'The Strength of Weak States: Adversarial Legalism in the US and the EU' (2009). Last accessed online 26.4 .2011 at http://www.euce.org/eusa2009/papers/kelemen 10B.pdf
} 
legal authority from singular interests, to connect individual persons directly to the legal apparatus, and to increase popular confidence in the legal system. This, in turn, has meant that individual persons are more inclined to utilize the law as a social facility. The result of this, then, is that society as a whole enters a more immediate and evenly inclusive relation to the legal/political system, and the political system is able to conduct more uniform process of legal inclusion, and to generate greater, and more effective, reserves of law for society.

One illuminating example of this is again Argentina. As discussed, during the Argentine transition to democracy in the 1980s, symbolically elevated importance was assigned to international human rights norms. By 1994, the constitution of Argentina was fundamentally amended, and a number of international human rights treaties were directly incorporated in domestic constitutional law. Of course, this process, conducted by Menem, a President hardly renowned for assiduous adherence to norms regarding legislative procedure, has often been derided, and it is disputed whether these treaties gained real purchase. ${ }^{149}$ Nonetheless, at this time, the growing standing of international human rights in Argentina had the manifest outcome that it led to a change in popular legal consciousness and common attitudes to legal inclusion. Throughout the longer period of transition, the law per se assumed greater importance as a medium of conflict resolution, both between private parties and the government and between private parties themselves, reflecting a generally increasing regard for judicial actors as norm providers for society. For example, the number of cases brought before Argentine courts increased dramatically in the longer post-transitional era, and in the period 1991-2002 the total number of cases filed increased by more than $100 \%$. This growth of judicial activity was most pronounced in the cases brought before the Supreme Court, which rose from just over 5,000 to almost 42,000 per year in the same time-span. ${ }^{150}$ Through this process, the (notoriously deficient) reach of the political system was greatly extended, and the

\footnotetext{
${ }^{149}$ See Mugambi Jouet, 'The Failed Invigoration of Argentina's Constitution: Presidential Omnipotence, Repression, Instability, and Lawlessness in Argentine History.' The University of Miami Inter-American Law Review 39(3) (2008): 409-462; 461; Diana Kapiszewski, High Courts and Economic Governance in Argentina and Brazil (Cambridge: Cambridge University Press, 2012), pp. 8, 31, 92.

${ }^{150}$ Catalina Smulovitz, 'Petitioning and Creating Rights: Judicialization in Argentina' in Rachel Sieder, Line Schjolden and Alan Angell (eds), The Judicialization of Politics in Latin America (Basingstoke: Palgrave, 2005), pp. 161-186; 163.
} 
inclusionary force of the state's power increased visibly. Indeed, the fact that citizens showed increasing willingness to deploy law as a means of contestation meant that they engaged with state power a level of greatly increased immediacy. Single acts of legal mobilization thus formed an important societal bedrock for the political system.

Examples of similar processes can be observed in the recent history of China, although, clearly, China can only be placed at an early stage in the process of democratic transition and progressive rights compliance. In China, the (still incipient) assimilation of human rights norms in domestic law has mainly been shaped by Chinese membership of the WTO, which entails obligations in respect of rights observance and integrity of judicial office. ${ }^{151}$ China's accession to the WTO led, initially, to a lengthy process of judicial reform, assigning greater autonomy to judicial institutions and even sanctioning rudimentary procedures for judicial review, first, of administrative acts, and, then, of statutory legislation. ${ }^{152}$ This, in turn, stimulated a rise in popular access to law, an increasing perception of law as an independent, relatively apersonal social medium, and an exponential growth in the number of cases heard by the courts. ${ }^{153}$ In each respect, against a background marked until recently by a very dilapidated legal system and very low lawmaking capacities, ${ }^{154}$ the progressive assimilation of international rights law in China acted to heighten the abstraction of the legal/political system as a centre of social inclusion. Moreover, it simplified the application of state power to varied social actors and to varied localities and social settings, and it substantially raised the volume and consistency of law in Chinese society. ${ }^{155}$ It is a distinctive outcome of the growing openness of the Chinese

\footnotetext{
${ }^{151}$ Ljiljana Biukovic, 'Selective Adaptation of WTO Transparency Norms and Local Practices in China and Japan'. Journal of International Economic Law 11(4) (2008): 803-825; 818.

${ }^{152}$ For background see Susan L. Shirk, The Political Logic of Economic Reform in China (Berkeley: University of California Press, 1993), p. 48; Randall Peerenboom, 'A Government of Laws: Democracy, Rule of Law and Administrative Law Reform in the PRC.' Journal of Contemporary China 12(34) (2003): 45-67; 46.

${ }^{153}$ One observer states: 'The total number of cases handled by the courts grew dramatically throughout the 1980 s and much of the 1990s before levelling off at around 8 million cases a year': Randall Peerenboom, 'Judicial Independence in China: Common Myths and Unfounded Assumptions' in Randall Peerenboom (ed), Judicial Independence in China. Lessons for Global Rule of Law Promotion (Cambridge: Cambridge University Press, 2010), pp. 69-94; 75-6.

${ }^{154}$ Murray Scott Tanner, The Politics of Lawmaking in Post-Mao China. Institutions, Processes and Democratic Prospects (Oxford: Clarendon, 1999), p. 43.

${ }^{155}$ See Wan, 'Human rights and Lawmaking in China,' p. 728; Laura Paler, 'China's Legislation Law and the Making of a more Orderly and Representative Legislative System.' The China Quarterly 182 (2005): 301-18; 301.
} 
legal system to international norms that widened access to law has encouraged an increase in rights-based grievance. By consequence, this has served to activate and to reinforce more centralized appeal procedures, so bringing addressees of law in different spheres of society more immediately under national jurisdiction. ${ }^{156}$ Moreover, the rise in public litigation in China has led to a strengthening of central power against or at least alongside clientelistic network structures. ${ }^{157}$ In each respect, vitally, the rising significance of international rights norms in China has raised the internal legislative complexity, the adaptability, and - in consequence - the inclusionary autonomy of the state apparatus as a whole.

However, perhaps the most important example of ways in which the reception of international human rights law expands the law-making capacity of national judiciaries is contemporary Russia. In recent Russian history, recognition and enforcement of international human rights have of course remained very incomplete, and Russia has repeatedly been criticized in, and even threatened with ostracization by, the European Court of Human Rights (ECtHR). For example, in 2007 alone, the ECtHR heard 192 complaints against Russia, only six of which were settled in Russia's favour. Moreover, the latter part of the period of Putin's influence has clearly seen the reinforcement of a semiauthoritarian system of public law, in which constitutional counterweights to the executive have been weakened. Nonetheless, recent Russian history, especially during Putin's period of office, has witnessed an increase in the force of international human rights law. In itself, the Russian Constitution of 1993 gives high standing to international law, and it provides for non-negligible functions of judicial review in light of international human rights. ${ }^{158}$ Further, the ECHR came into force in Russia in 1998, and, although its efficacy is disputed,

\footnotetext{
${ }^{156}$ See Benjamin L. Liebman, 'China's Courts: Restricted Reform.' The China Quarterly 191 (2007): 620-638; 620-22, 636; John L. Thornton, 'Long Time Coming: The Prospects for Democracy in China.' Foreign Affairs 87(1) (2008): 2-22; 10.

${ }^{157}$ Kevin J. O’Brien and Lianjiang Li, 'Suing the Local state: Administrative Litigation in Rural China.' The China Journal 51 (2004): 75-96; 86.

158 Gennady Danilenko, 'The New Russian Constitution and International Law.' The American Journal of International Law 88(3) (1994): 451-470; Vladlen Vereschetin, 'New Constitutions and the Old Problem of the Relationship between International Law and National Law.' European Journal of International Law 7 (1996): 29-41. For background see Alexei Trochev, Judging Russia. The Role of the Constitutional Court in Russian Politics 1990-2006 (Cambridge: Cambridge University Press, 2006).
} 
it has impacted palpably and pervasively on judicial and legislative practice. ${ }^{159}$ In 2003 , notably, the plenum of the Supreme Court provided rules and recommendations regarding the application of the ECHR in domestic hearings. Since the landmark ruling in Maslov (2000), in which a judgment was formally supported by the ECHR, citation of the ECHR in Russian courts has increased, and the recognition for international rights norms, although still variable, has risen. Moreover, although in the recent case, Konstantin Markin v. Russia (2012), the ECtHR (to much protest) overturned one of its rulings, the Russian Constitutional Court has in general contributed greatly to the alignment of Russian law to ECHR standards, and it has repeatedly referred to the jurisprudence of the ECtHR in important cases. $^{160}$

As in other cases, the incorporation of international human rights law in Russia has had a deep impact on the structure of the political system, and it has helped to consolidate the political system as an autonomous centre of social inclusion. On one hand, the importing of international law into Russian jurisprudence has coincided (surely not by accident) with a sharp increase in the integrity of state institutions and a reduction in the standing of local or private power, ${ }^{161}$ and it has contributed to an increasingly consistent, although clearly partly authoritarian, ordering of the legal/political apparatus. Notably, throughout the 1990s, the political system in Russia was exposed to endemic and protracted legal and political collapse, in which the private arrogation of public resources (office grabbing) posed a virulent threat to public order. ${ }^{162}$ One salient consequence of this process was a deep public alienation from state institutions, and a common deep

\footnotetext{
${ }^{159}$ For an early balanced view of Russia's compliance (or otherwise) with the ECHR, see Bill Bowring, 'Russia's Accession to the Council of Europe and human rights: Four years on.' Helsinki Monitor 11 (2000): 53-72.

${ }^{160}$ See Sergei Yu. Marochkin, 'International Law in the Courts of the Russian Federation: Practice of Application.' Chinese Journal of International Law 6(2) (2007): 329-344; 333, 341; Angelika Nußberger, 'Wer zitiert wen? - Zur Funktion von Zitaten bei der Herausbildung gemeineuropäischen Verfassungsrechts.' JuristenZeitung 61 (15/16) (2006): 763-770; 766-7.

${ }^{161}$ See Philip Hanson and Elizabeth Teague, 'Bug Business and the State in Russia.' Europe-Asia Studies 57(5) (2005): 657-680; 657.

${ }^{162}$ Putin specifically promoted judicial reform as a means for enhancing state capacity. See Anders Fogelklou, 'Constitutional Order in Russia: A new Territory for Constitutionalism.' Review of Central and East European Law 26(3) (2001): 231-257; 244; Peter Solomon, 'Assessing the Courts in Russia: Parameters of Progress under Putin.' Demokratizatsiya (161) (2008): 63-73; 66.
} 
'disregard for the rule of law'. ${ }^{163}$ Against this background, despite intermittent controversy, the gradual promotion of legal rights has served as a method for stabilizing the legal system, for consolidating the authority of the law in society, and for establishing consistent foundations for the transmission of public power across society. In addition, the rising importance of external rights in Russia has clearly widened common access to the law, it has increased public willingness to use law as a means for addressing perceived violation, and, because of this, it has stimulated a dramatic increase in litigation, and in law's inclusionary force, across different parts of Russian society. Tellingly, the period of Putin's influence has witnessed an exponentional rise in anti-government litigation, facilitated by new legal codes. In 2002, importantly, Putin introduced the Civil Procedure Code, which enabled Russian citizens to challenge political decrees before the Supreme Court. In addition, the number of civil cases heard in court increased by well over $100 \%$ in approximately the same time-span. ${ }^{164}$ Naturally, this increased use of law has been in some respects unsettling for the political order, as it included prominent cases regarding misuse of public office, and excessive use of force against political dissidents. Yet, the increase in the size of judicial caseloads has reflected a growing societal demand for law, indicating a rising confidence in the legal/political system as a source of public arbitration. In turn, this has brought social agents in different, geographically diffuse parts of society into a more immediate, controlled and inclusive relation to the political system, and it has raised general compliance with public legal directives. ${ }^{165}$

In these respects, arguably, the assimilation of international rights norms into Russian law ultimately formed a normative premise on which society came to depend for its basic, constitutive ability to spell out a grammar of public law amidst highly disordered

\footnotetext{
${ }^{163}$ Anna Grzymala-Busse and Pauline Jones Luong, 'Reconceptualizing the State: Lessons from Post-Communism.' Politics and Society 30(4) (2002): 529-554; 545.

${ }^{164}$ Richard Sakwa, 'The Dual State in Russia.' Post-Soviet Affairs 26(3) (2010): 185-206; 201. For statistics see Kathryn Hendley, "'Telephone Law" and the "Rule of Law": The Russian Case.' Hague Journal on the Rule of Law 1(2) (2009): 241-262; 243. Civil law cases rose from 2881.6 in 1997 to 9009.0 in 2007 . Hendley also notes the link between increasing confidence in law and protection of rights (244). For discussion of the linkage between civil and private litigation and general solidification of political structure see Frances Kahn Zemans, 'Legal Mobilization: The neglected Role of Law in the Political System.' The American Political Science Review 77(3) (1983): 690-703; 701; Giles and Thomas D. Lancaster, 'Political Transition, Social Development, and Legal Mobilization', p. 830.

165 On both these points, see Katharina Pistor, 'The Demand for Constitutional Law.' Constitutional Political Economy 13 (2002): 73-84; 74.
} 
conditions of government, marked by a high level of institutional privatization. In particular, international law assumed significance in this setting because it made it possible for society distinctively to identify and apply certain statutes and procedures as legitimate and discernibly lawful. Through this, citizens were enticed to engage with law as a medium of social interaction, and the legal/political system acquired the capacity to perform functions of inclusion in simplified and increasingly independent fashion. To this extent, international law was absorbed in Russian law, however fitfully, because it enabled institutions in Russian society to refer to an underlying definition of law's public authority. Human rights, derived from international law, created a matrix in which society was able to underline distinctions between lawful power and non-lawful power and between authentic law and mere private command, and it offered a residual source of legitimacy for legislation in a political landscape otherwise shaped by at times extreme structural fragmentation. This would appear to be the vital trade-off between the national and the international legal domains in recent Russian history. Actors in the Russian political system would appear to be willing to accept criticism from international rights tribunals, and from domestic courts applying international human rights law, because the recognition of international jurisdiction means that the Russian state as a whole acquires external authorization for its laws. This means that the state obtains the benefits (however partial) of public inclusion, institutional hardness, evenness in legislation, and perceived public legitimacy, through which they can distil law - however imperfectly - as an apersonal, reasonably generalized medium of inclusion. To this degree, the interaction of domestic law with international human rights law plays a key role in heightening the structural power of the state, and in enhancing the state's powers for circulating law through society. Indeed, as in other cases, the increasing consolidation of the legal system around international rights norms in Russia underpins the extraction of a system of public law (or even of law tout court) in a setting which had previously, for deeply embedded sociological reasons, veered towards extreme privatism, and resisted the formation of a clearly public legal order. As a result, this makes it possible for the state autonomously to create, legitimate, and apply law across all society. 
In these different examples, it is observable that the rising impact of international human rights law on national political systems often has the simple functional outcome that it allows societies dramatically to raise the volume of law that they can produce and apply. In many instances, the rise of human rights permits - at least in part - a transfer of de facto law-making power from legislatures to judiciaries. The fact that judicial rulings are supported by international human rights norms enables courts to assume a more prominent position in legislative and quasi-legislative activities, and it means that society can meet manifold and challenging demands for law without losing consistent legal structure. Furthermore, the rise of rights means that judicial bodies play a more important role in factually solidifying law as an inclusionary medium in society, and thus in augmenting the volume of real law that society possesses and consumes. These processes have particular importance in national societies which, for various reasons, have struggled to generate law to meet their inner inclusionary demands, and which are marked by tendencies towards state fragmentation and privatization. In such cases, the acquisition of normatively regulated law-making force by courts has crucial importance in elevating the inclusionary force and the effective sovereignty of the political system across society. However, the extension of society's law-making power through the assimilation of international human rights law can be seen as a quite general phenomenon, which brings structural benefits for all states and all societies, at different stages of functional evolution.

\section{CONCLUSION}

This article proposes a sociological approach to the increasing importance of international law, and especially to the growing force of international human rights law. The claim at the centre of the article is that the growth of international human rights law is closely bound up with functional exigencies that are embedded in national societies, and it cannot be separated from the classical historical processes that determined the construction of public law and public institutions in national legal and political systems. In particular, the rise of international human rights law enables national societies to soften, and even to rectify, problems of legal/political formation that lie deep in their historical structure. The process of assimilation of international human rights accelerates and 
simplifies national legislative and judicial procedures, it diminishes the reliance of the political system on external actors, and it reduces its susceptibility, in both its legislative and judicial dimensions, to over-politicization, to external colonization, and, in particular, to re-privatization. The assimilation of international rights norms in national law, at core, acts both to heighten the basic differentiation of the national political system, and to facilitate the relatively even distribution of law and power through national society.

Underlying this account of the interaction between national and international law is the assertion that the national state originally evolved as an order of legal inclusion. As such, it was fundamental to the national state that, as its functions incrementally expanded, it was expected to reach more deeply and more widely into society for support, and so, also, to resolve more and more conflicts ingrained within society. Through the course of its development, however, the national state generated requirements for inclusion that placed unmanageable burdens on national political institutions, and which could not be fulfilled at a national level, through resolution of national conflicts by nationally localized actors. As a result, national states began to borrow norms from the sphere of international law to address their inner structural pressures, and problems of inclusion that had not been soluble in national law became - partly - soluble through international law. Accordingly, international human rights law grew, sociologically, out of national law, through a process of functional displacement or functional overspill. International human rights law became prominent because of its utility within national societies as a medium for correcting or softening inclusionary structural pressures which had traditionally prevented national states from operating effectively as sovereign states within their national environments. This means that, if we observe state building as a process of publicly inclusive institutional construction, the trajectory of national state construction only really began to approach completion at the moment at which national states were integrated into the rights-based transnational legal/political order. The fact that a national political system could derive legitimacy and inclusionary reinforcement from international law was often the precondition for the existence of an effective (i.e. sovereign) national political system. In fact, in many cases, it is only as national political institutions converged with, and drew support from, a transnational system of legal and 
political norms that we can truthfully speak of modern societies as having a differentiated and relatively autonomous legal/political system. It was only when the national political system in its strict form had dissolved that it became effective (i.e. sovereign).

In each respect, the key to the sociological importance of international human rights law is that it induces within the political system a shift from externalistic sources of legitimacy (inclusion of labour, mediation of class conflict, resolution of centre/periphery conflicts) to a more internalistic source of legitimacy (human rights). This internalization of the source of legitimacy facilitates a far-reaching de-politicization of the legislative dimensions of the national political system, and this de-politicization underlies the differentiation of the political system as a relatively stable and autonomous functional order. Seen from this perspective, human rights trace out the final differentiation of the national political system, and they allow the national political system to reproduce itself and perform highly flexible, geographically overarching functions of inclusion without unsettling reliance on external structural support. In addition, human rights enunciate the basic code through which national political systems are incorporated into the growing transnational political system: human rights form a register in which national and transnational aspects of the global political system interact with one another, and are locked together. It is only through the global re-definition of the political system as founded, not in the results of external conflicts, but in internationally determined human rights, that a fully autonomous and differentiated political system has been able to evolve. 